\title{
«CORONAVIRUS» COMO MANCHACHI NOTAS ACERCA DE LAS CONCEPCIONES Y CONDUCTAS ANTE EL MIEDO
}

\author{
Luis Mujica Bermúdez \\ Universidad Nacional José María Arguedas
}

\begin{abstract}
Resumen: El artículo analiza el significado del término manchasqa o mancharisqa (asustado) en tiempos del coronavirus o SARSCov-2 entre los pobladores en una zona andina quechua y las conductas que adoptan ante la amenaza de la expansión del virus en el contexto de emergencia dispuesta por el Gobierno peruano. Se revisa el concepto del «susto» (manchasqa) recurriendo a la tradición mítica quechua, a la médica, a las ciencias sociales y a las humanas, como la psicología y la filosofía. Se propone una tipología, a modo de hipótesis, de las formas de entender el mancharisqa (estar asustado) en una zona de los andes.
\end{abstract}

Palabras clave: miedo, mancharisqa, susto, mundo andino, coronavirus. 


\title{
«Coronavirus» as Manchachi Notes about Conceptions and Behaviors in the Face of Fear
}

\begin{abstract}
The article analyzes the meaning of the manchasqa term or mancharisqa (scared), at the time of the coronavirus or SARSCoV-2, among the people in Andes Quechua, and behaviors that take the threat of the spread of the virus in the context of emergency arranged by the Peruvian Government. The concept of 'scare' is reviewed, drawing on the mythical Quechua tradition, the medical tradition, the social sciences and the human sciences, such as psychology and philosophy. A typology is proposed, as a hypothesis, of the ways of understanding mancharisqa (being scared) in an area of the Andes.
\end{abstract}

Keywords: Fear, Mancharisqa, Fright, Andean World, Coronavirus.

\section{Luis Mujica Bermúdez}

Doctor, magister y licenciado en Antropología, profesor principal de la Universidad Nacional José María Arguedas, Andahuaylas. Miembro del Grupo de Investigación de Conocimientos Andinos (GICA) y del grupo Unaypacha de la UNAJMA; es investigador asociado al INTE-PUCP y miembro del RIDEIPUCP.

Agradecimientos: Agradezco a Edwin Félix y Erika Loa, quienes me hicieron llegar sus comentarios y observaciones al texto.

Correo electrónico: lmujica@unajma.edu.pe 


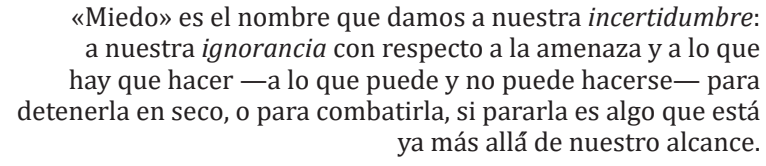

Bauman (2007: 10)

\section{Introducción}

El 12 de marzo de 2020, una noticia comenzó a correr a través de redes sociales entre los andahuaylinos: «Se confirmó en ESSALUD de Andahuaylas, 2 pacientes con coronavirus que viven en San Jerónimo dieron positivo, que Dios se apiade de nosotros. No salir de sus casas, y comprar alimentos no perecibles para muchos días²».

Ello desató una ola de comentarios en redes. Alguien reenvió otro mensaje: «106 SAMU, 113 MINSA, 515200 DIRESA, 041118000 ESSALUD. Serán atendidos en sus domicilios [...] por personal capacitado [...] No salir de ahí si tienes algún síntoma. Ayuden a difundir [...]». Finalmente, alguien más compartió un video de YouTube «sobre cómo prevenir el coronavirus». La ola de comentarios se detuvo, relativamente ${ }^{3}$.

En paralelo a esas actividades en redes sociales, el «boca en boca» empezó a transmitir «noticias» sobre tiendas que eran invadidas por cientos de compradores, que incluso se hacían largas colas para llevarse productos cuyos precios, en algunos lugares, se habían elevado. Y que el alcohol, el jabón y las mascarillas, cuyos precios también se dispararon, habían desaparecido de las boticas. Saludos con besos en las mejillas y darse las manos, entre tanto, comenzaron a ser reemplazados con toques de los codos o con el movimiento de las manos a distancia.

2 Hecho que no era verdad, pero no había manera de comprobarlo.

3 El 1 de abril se confirmó en Andahuaylas la presencia de una persona (o familia) contagiada de Covid-19. El miedo se incrementó. Esta noticia me llegó cuando trataba de acabar este texto. La emoción de verse rodeado por la incertidumbre se incrementó, así como la confianza comenzó a desvanecerse. 
Se empezaron a tejer noticias-hipótesis de un «extranjero» que llegó a Andahuaylas por avión y que fue encerrado en cuarentena, y se puso en duda la salud de los 19 pasajeros que llegaron en ese vuelo, cuyo paradero era desconocido. Las noticias cundieron por todas partes, los celulares se usaban para abrir notificaciones o links para saber el número de casos en Lima y otras ciudades. Los medios de comunicación exaltaban la «ferocidad» del coronavirus y las muertes que iba causando en el mundo, sobre todo en la población adulto mayor.

Así, la ola que partió desde Wuhan, en China, pasó por Europa, generando crisis, cerrando fronteras y mercados, prohibiendo los lugares de concentración de la población, y llegó a América. El creciente número de contagiados obligó entonces a los Gobiernos a entrar en alerta, se suspendieron actividades académicas y escolares. A nivel regional, las autoridades locales, finalmente, suspendieron las celebraciones de Semana Santa.

Como resultado, hay quienes han tomado nota de los hechos y sienten que la respuesta se encuentra en la prevención. Otros creen que no les pasará nada y han tomado el estado de emergencia como un tiempo de «vacaciones». En los lugares públicos el agua y el jabón son ahora una obligación, las personas que venden en los mercaditos reciben el dinero con la mano cubierta de plástico, todos caminan con mascarillas. Estos hechos, inéditos en diferentes zonas altoandinas y también en Andahuaylas, han cogido desprevenida a toda la población, la cual comienza a padecer los síntomas de estar mancharisqa.

El miedo genera irritación (waqapakuy), preocupación (llaki), nerviosismo (katkatay), insomnio y sobresalto (pacha wischuy), confusión (muspay), estrés (llakllasqa), dolor de cabeza (uma nanay), entre otros. La conducta humana se trastoca y no se logra distinguir la fuente de sus males; unos imitan a los otros, y entre esos otros abundan los que se creen invulnerables y no acatan las reglas. El miedo hace comprar cosas que se cree se van a terminar, esto crea escasez, que genera ansiedad y angustia; la cadena de necesidades crea más vacíos y más necesidades.

$\mathrm{Y}$ todo esto es causado por un pequeño «enemigo invisible» y no conocido (mana riqsisqa) denominado coronavirus o Covid-19 o SARS-CoV-2. Estos hechos sociales requieren ser registrados y pensados colectivamente para entender lo que está pasando en la conducta humana y social.

Hay que recordar que hace 500 años, América Latina y el Perú ${ }^{4}$ sufrieron el impacto de males «desconocidos». Los andes padecieron y 
su población casi desapareció por las enfermedades «no conocidas» 5 , reduciéndose a cifras no del todo conocidas hasta ahora. A raíz de ello, el desarrollo de las ciencias en los andes se «congeló» - como dice Lumbreras (1991) - y con ello los intelectuales locales prácticamente desaparecieron y la formación de una sociedad sostenible se desdibujó en pocos años.

Así, se llevó a cabo un etnocidio a través de la explotación y abuso de las mineras de ese entonces, pero también por las enfermedades traídas del «viejo continente» (junto con otros sistemas de opresión) (Cook 1999, Cotler 2006, Roca 2016, Santa María 2017). Estos males vinieron para quedarse y causaron estragos durante siglos. Por ejemplo, Palomino $(2014)^{6}$ recuerda que en Ayacucho de 1922 hubo una ola de enfermedades que generaron mucha preocupación en la población:

El Sarampión, la Gripe y el Coqueluche fueron las enfermedades más recurrentes y responsables de la muerte de niños en su mayoría; sin embargo, también el Tifus y la Tifoidea tuvieron gran impacto en el estado sanitario local presentándose, con mayor arraigo para 1922, en los barrios de San Blas, Santa Teresa, Tambo y Soquiaca. (2014: s/p)

Entonces, las amenazas de «enemigos invisibles» no son nuevas, estamos marcados por una historia de diversas formas de etnocidios.

Ahora vamos a partir de una afirmación, la que será seguida de un análisis antropológico, tomando en cuenta algunas categorías del mundo quechua: El miedo (manchay o manchakuy) es generado o causado por lo no conocido (mana riqsisqa y wamaq). Este miedo produce a un sujeto manchasqa (preocupado), también mancharisqa (asustado o angustiado), que actúa de manera atípica, confusa y errática (panta pantasqa).

Para ampliar esta afirmación tomaremos en cuenta 1) los datos lingüísticos y los significados del miedo (manchay o manchakuy); 2) revisaremos la manera de entender el susto en los sujetos «asustados» (manchasqa o mancharisqa) desde diversas disciplinas; 3) mostraremos las diversas expresiones del miedo (manchakuy) y una tipología; 4) para reflexionar algunas de las implicancias político culturales en tiempos de miedo (manchaypacha); 5) finalmente se presentará una pequeña conclusión.

\footnotetext{
5 La viruela y el sarampión eran enfermedades conocidas por los europeos, pero algo completamente extranjero para América.

6 Cueto (2000), en un importante trabajo, recoge información sobre las epidemias en el Perú, entre estas: la peste bubónica, que afectó a las principales ciudades de la costa peruana entre 1903 y 1930; la epidemia de fiebre amarilla entre 1919 y 1922, que afectó en la zonas de la costa norte; el tifus y la viruela en los andes, durante la década de los treinta; la malaria, una enfermedad endémica en el siglo XX, sobre todo la epidemia que ocurrió en 1932 en Quillabamba, Cuzco; la epidemia de viruela en la zona de Ayacucho en el año 1943; finalmente, la epidemia del cólera de 1991, que afectó a casi todo el país.
} 


\section{Miedo: manchay y manchakuy}

Estos tiempos son de manchaypacha, tiempos de miedo. El término miedo proviene del latín metus, pero su origen es incierto; en el griego existe el término fobos (fobia) para decir lo mismo; y en el quechua existen términos como manchay y manchakuy. Manchay es el sustantivo y verbo que equivale a miedo y manchakuy es el miedo, pero interno, que se construye en la persona. Estos términos aparecen de muchas maneras en el vocabulario de González Holguín (1989 [1698]), a quien recurrimos como fuente importante para dialogar con expresiones quechuas comunes de hoy. La persona que tiene miedo es el mancharisqa. Tener miedo o temer es manchani, aunque sería mejor decir manchakuni. Lo que genera miedo es alguien o algo, y esto es el manchachi. Este elemento puede generar una situación: mancharayani, es decir, «estar o durar mucho con temor, atemorizado». Pero también genera una condición: manchaykachani, es decir, se trata de un «andar con temores como en tiempo de peste» $y$, hoy en día, se dice «andar asustando» o «produciendo miedo». Finalmente, el manchaq sunqu o llakllaq sunqu es la persona que tiene miedo o se mantiene tímido.

Sin embargo, hay otras acepciones, las que mencionaremos brevemente. Al hombre respetable o a la autoridad se le conocía como manchay runa o manchayniyuq. Es probable que ese manchay era en la medida que la autoridad, por el poder que sustentaba, era considerado como diferente. El término manchana (con el sufijo sustantivador -na) se convierte en alguien de temer, como dice González Holguín: «por su condicion ayrada, o el Juez riguroso, o Dios castigador». Entonces, el término manchana manchayniyoc es el «hombre de autoridad y respeto». Por lo tanto, producir miedo sería manchaykuchini llakllaykuchini; vale decir que manchachini es «atemoricar o espantar a alguno»; pero también se puede decir manchaykachini, que tiene el mismo significado. Dejemos estas notas aquí.

Por otro lado, existe otro término quechua para decir miedo (profundo) y es llakllay. Al sujeto que tiene miedo o temor muy grande se le dice Ilakllasqa y es la persona que anida un temor profundo dentro de sí. El término, siguiendo a González Holguín, llakllarquni es «acabar de perder el ánimo, o no tener brío, o temblar de miedo». Llakllakuni, por ello, es «andar tímido medroso» como consecuencia de choques sufridos en la vida. El texto señala una situación en la que se constata la condición de una persona en la que el miedo ha calado profundamente y lo deja como sin fuerzas. De ahí que el término llakllayachini es «hazer temer, o desmayar, o desanimar, o acobardar». Esto significa que llakllay es sinónimo de timidez o de temor - las ciencias humanas las denominan de varias maneras- y se trataría de una actitud disminuida y temerosa en relación a algo o alguien. Por ello, a la persona que es tímida se le dice llakllarayaq. El término llakllapayan 
indica que se trata de una persona que tiene demasiado temor y tiende a acobardarse. Esta tradición continúa hoy y de hecho una persona temerosa o miedosa es llamada llakallasqa runa; algo así como una persona «con un miedo grabado internamente».

El término manchakuy está asociado a la persona que tiene miedo, a quien se le dice manchakuq. El sufijo -ku es un sufijo reflexivo que indica que el miedo está en la persona misma, en su $u k u$ (cuerpo o persona). No conocemos la naturaleza de ese miedo, pues solo se dice que está mancharisqa (asustado) y el origen de ese miedo es algo «desconocido», aunque culturalmente se le puede atribuir a diversas causas, como a una caída, un ruido inusitado, el encuentro con un animal, la impresión causada por un evento natural, la violencia de cualquier tipo. La sensación que el sujeto experimenta queda en su interior y causa diversas reacciones en su persona. El miedo es, sin duda, una emoción que la persona siente y que en tiempos difíciles puede «contagiarse» a otros, aun sin proponérselo. ¿Qué causa ese miedo? ¿De dónde proviene? ¿Qué consecuencias genera?

Es probable que el miedo que una persona tiene sea la sensación de confusión y de desequilibrio que siente en su interior (uku ukunpi). El sentimiento de la persona se trastoca a tal punto que sus coordenadas se diluyen y su conciencia entra en un túnel —aparentemente- sin salida. Sus puntos de referencia se desdibujan y las señales que la guían se alteran notablemente, hasta dejarla desorientada y sin rumbo. Entonces, la naturaleza del miedo desdibuja el orden interno y somete a la persona al silencio o al alboroto sin control. La persona queda a merced del sin sentido y de la idiotez. La anomia se instala en su mundo interior y la anarquía queda expedita para la acción. El que tiene miedo se encierra en su mundo y solo piensa en sí mismo (y en su familia). Actúa como víctima perseguida por el deseo de la sobrevivencia y, en última instancia, el deseo de perdurar a pesar de todo.

¿Qué trastoca el miedo? El manchay afectaría profundamente las dimensiones del runa. Esto implica tener una concepción del ser humano entre los andinos que requiere ser estudiada ${ }^{7}$. El ser humano andino concebiría su «cuerpo» como un mundo multidimensional que estaría conformado por el hawa (su identidad externa), su $u k u$ (sus organismos físicos), su chawpi (su campo físico-emocional) y su $u k u$-uku (su interioridad o mundo interno) (Mujica 2019). Sin embargo, al parecer, el miedo se instalaría en el campo del yuyay (memoria), del munay (voluntad) y del ukusunqu (conciencia), que son partes del uku-uku. La memoria sería sinónimo de garantía; la voluntad, sinónimo de seguridad; y la conciencia, sinónimo de vigilancia. Cada una de

\footnotetext{
Hasta ahora, la concepción dual o diádica del ser humano, que resulta siempre dicotómica en su interpretación, es la que se mantiene en las disciplinas que atienden la salud de las personas.
} 
estas partes son las que se alterarían por el miedo. Estas partes requieren de una pequeña explicación.

En primer lugar, la memoria (yuyay), en el mundo andino, es sinónimo de adultez, de sabiduría, de garantía. En circunstancias de crisis estas cualidades se resquebrajan y en muchos casos se paralizan, se trastocan y pasan a un momento de estancamiento; pero también de insensibilidad para la adaptación. Todo lo aprendido se desactiva y aparece lo más primario y elemental: la necesidad de sobrevivencia y los emprendimientos fundamentales. En cierto sentido, se activan los mecanismos más básicos que empujan a cada individuo a resolver lo suyo y lo de su familia, y enfrentar a lo no conocido. Los códigos de las relaciones sociales se borronean o se los deja de lado. El comportamiento «adulto» de la responsabilidad pareciera que se esfumara para dejar paso a la competencia y aguzar las mejores estrategias para sostenerse en tiempos adversos. Los conocimientos y la sabiduría aprendidos en el tiempo, y que podrían encaminar a orientar la vida en una situación de necesidad, se suspenden y se hace uso de diversas estrategias para lograr los objetivos más elementales. Recordar el pasado no tiene validez y el futuro incierto cierra las fronteras de ese pasado y solo vale lo que hay que hacer para hoy y el mañana inmediato.

La memoria que debiera sostener la data histórica, la información ordenada y el conocimiento existente, sufre una cierta paralización de aquello que activa las ideas y lo que ayuda a buscar soluciones a los problemas. La memoria se estrecha y no activa necesariamente la solidaridad ni la ayuda mutua. Ejemplo, el ayni, en la ciudad, desaparece y se incentiva la «recolección» (compra) de productos en las tiendas o en el mercado. La memoria se difumina y se estimula la práctica reactiva de «salvarse» a sí mismo y hacer «negocio» en tiempo de crisis. Sin embargo, la memoria también se activa, y se recuerda que hay productos que siempre han existido en la región con mejores valores proteicos y vitaminas.

En segundo lugar, la voluntad (munay) es sinónimo de aplomo, fortaleza y seguridad; pero en tiempos de crisis trastabilla y el poder que la persona cree tener se diluye, dejando la posibilidad de sembrar la anarquía. Dentro de esa anarquía devienen sentimientos de «invulnerabilidad» y la idea de la «inmortalidad» se instala en las profundidades de la persona, haciéndola más individualista y trastocando las reglas de las relaciones sociales. Una vez quebradas las reglas sociales, la anomia queda suelta como el «loco para». «Loco para», para los agricultores, es la lluvia torrencial que cae con fuerza, que genera riachuelos, riadas, torrenteras, y arrasa lo que encuentra a su paso. Esas gotas de agua que caen con fuerza, juntas, tienen una potencia inusitada e incontrolable y causan desastres con consecuencias impredecibles. Al terminar la lluvia se terminan las riadas o los huaycos, 
pero las consecuencias de estos fenómenos naturales, muchas veces, suelen ser cuantiosos.

El miedo en tiempos de crisis anula o disminuye la voluntad de las personas y en ocasiones las paraliza, sin dejar la posibilidad de salir de esa parálisis. El miedo se instala en las miradas huidizas de niños, mujeres y varones que se sienten disminuidos ante otros, porque no pueden sostener una mirada ante el otro que se presenta como un inquisidor. A menudo, bajar la vista es una forma de someterse al poder, es la munay que se desvirtúa. Los tratamientos sociales borran los nombres propios de las personas y son reemplazados por grados o gentilicios. El tratamiento de «doctor», «magister» o «licenciado», por ejemplo, hace que las relaciones de subordinación se mantengan, reproduciendo las conductas de subalternidad que rememoran las relaciones sociales de tiempos del gamonalismo y de las haciendas.

Finalmente, la conciencia (ukusunqu) es el espacio de la resistencia, de crítica y de vigilancia; pero en tiempo de crisis también tiende a obnubilarse, oscurecerse y ocultar realidades. Es el último rincón que el ser humano mantiene para sí, es el lugar de reserva para dirigir su propia existencia; pero muchas veces queda mudo y se tiñe de sombras. La reserva «espiritual» de protección de sí mismo y de sus relaciones con los otros se licúa hasta dejar de ser gente o runa ${ }^{8}$. Algunos dirían que el comportamiento «animal», sin razón ni razonamiento, regresa. Sin embargo, la «animalidad» es solo un adjetivo valorativo de la acción de algunos que se aprovechan de las circunstancias para beneficio propio. Es como si el «espíritu» hubiera muerto por momentos y se instalara la racionalidad instrumental que consiste en adecuar medios para fines privados. Vale decir que la misma definición de cum-scire, de donde proviene la palabra conciencia, se desvirtuara radicalmente; pues el prefijo cum significa colectividad y scire es conocimiento; entonces, el conocimiento compartido con otro desaparece. En efecto, en momentos de crisis la conciencia se ensombrece para que unos saquen provecho de la aflicción de muchos otros.

La conciencia ensombrecida da cabida a las acciones básicas y de protección de lo suyo (familia) y se reactivan las «creencias» personales en sus diversas expresiones. Las formas de conocimientos básicos decrecen, para buscar las justificaciones necesarias que cubran la tendencia inmediata y dejen de lado las relaciones con los otros, empezando por los más distantes. Cuanto mayor sea la distancia emocional con los otros, es menor el interés que se tiene por estos. En redes sociales, alguien decía: «Ahora me toca atender a mi familia», y en otro post se leía:

8 En la zona de Junín a la gente se le dice nuna. Este término, en otros lugares, equivale a espíritu o alma. Ver Vocabulario Políglota Incaico (1998 [1905]). 
[...] Este es un buen momento para estar con la familia y acercarnos más a Dios. Tranquilidad y siempre con la precaución del caso estar en casa. Muchos estaremos bien, pero hay quienes viven el día a día de su trabajo informal es ellos ahora los que necesitan q [sic] alguien les extienda una mano.

En otras palabras, que sea otra persona la que extienda la mano para ayudar.

\section{El miedo en la cultura y las disciplinas}

El miedo forma parte de la condición humana y tiene historia. Para este caso, recogemos brevemente tres tradiciones culturales: la mítica, la de las ciencias médica y social, y la de la psicología y la filosofía.

En primer lugar, José María Arguedas (2012a) recoge narraciones vinculadas al miedo a través de cuentos o narraciones. En este caso, resumo dos. La primera es «Espíritus burlones» (2012a: 111-113); en este cuento, dos jóvenes van a buscar a sus enamoradas a un lugar distante. De noche, a medio camino, los jóvenes ven a dos muchachos vestidos de blanco arrodillados frente a una cruz. "Semejante escena, a tales horas de la noche, sorprendió vivamente a los dos jóvenes que sintieron un miedo extraño, a tal punto que se les pararon los pelos y comenzaron a temblar» (2012a: 111). Pese a ello, siguieron con su camino, pero los dos jóvenes sentían que algo (un bulto) les seguía y les tiraba piedras a sus pies, «¡Manchaculcanampaj! (¡Para que se asusten! $)^{9}$ [sic]». La «presencia» misteriosa era de los «condenados», quienes les impidieron llegar donde sus enamoradas. La moraleja de la historia es: «Este suceso les sirvió de ejemplo para que no fuesen lejos a altas horas de la noche» (2012a: 113).

El siguiente cuento de Arguedas (2012b: 214-221) —escrito en quechua y castellano- es «Ararankaymanta» («El lagarto») ${ }^{10}$. El cuento trata de una pareja rica que no logra tener hijos, por lo que recurren a la religión para tenerlo. Más de diez años después, la mujer finalmente queda embarazada, pero da a luz a un bebé con cabeza de persona y cuerpo de lagarto. El niño se hace hombre y busca casarse. Pese a que la gente sabe la situación del hijo, el dinero de los padres es suficiente aliciente para que puedan encontrarle una esposa. En la noche de bodas, el lagarto devora a su primera esposa, y hace lo mismo con las siguientes, hasta que el rumor de sus crímenes se extiende y nadie quiere ofrecer a sus hijas. Finalmente, una joven muy pobre 
ofrece casarse con el lagarto. Pero la joven, antes de ir a la noche de bodas, es instruida por una layqa (bruja) para que el lagarto sea quien se acueste primero, además de seguir una serie de instrucciones. Así, esa noche, la joven pone sus condiciones, y tras una discusión, hace que el lagarto se acueste primero. En medio de la oscuridad (que es como debe permanecer todo el tiempo, según la bruja), la joven oye un ruido: el lagarto se saca su caparazón. Acto seguido, la joven enciende la luz, pese a que la layqa le indicó que no debía mirar, pero: «Chayta mana yuyaspa. 'Qunqaytaq mikuruwanman kay hina ararankaytaq kachkan', nispan; qawaykusqa vilawan» ${ }^{11}$. (No recordó aquello. «Pueda ser que me devore porque está ahí el lagarto», diciendo esto miró con la luz de la vela). La joven vio no un lagarto, sino a un joven bello, pero este se desvaneció entre sus brazos por desoír los consejos de la bruja. Después de estos hechos, la joven fue considerada como nuera de la pareja rica y se quedó en su casa. Sin embargo, la gente siguió murmurando contra la madre: «Después que mueras, una serpiente mamará de uno de sus pechos y del otro un sapo. Ese será tu castigo. Pediste lo que no quiso darte. Jamás tendrás hijos» (2012b: 221).

Por su parte, Itier (2004) recoge cuentos en la zona sur del Cusco, uno de estos —en quechua y castellano- se titula «Joven-de-quince-años» (2004: 64-75). Un joven de una familia pobre, pero muy comelón, busca trabajo y para ello decide viajar a otro pueblo. En el camino se encuentra con un puma y luego con un oso, a quienes les gana en competencias y se hacen «hermanos». En la ruta, por turnos, uno se queda a cocinar mientras los otros dos van a realizar labores. Pero cuando están listos los alimentos, alguien siempre pide comida al que está cocinando antes que regresen de la faena los otros dos, por lo que estos se quedan sin comer. Al final, al Joven-de-quince-años le toca el turno de la cocina y descubre que quien pide la comida era una cabra; para proteger la comida de sus hermanos, corta una de las orejas del animal y lo hace huir. Siguiendo las huellas que dejan las gotas de sangre, el trío llega hasta una cueva vertical. Allí, tanto el puma como el oso, al bajar, sienten miedo y retornan a la superficie sin poder enfrentar el peligro que veían en el fondo de la cueva. El Joven-de-quince-años decide entrar con una espada, mata alimañas y se enfrenta al diablo mismo, a quien reduce a pedazos, liberando a una joven que le entrega un anillo para casarse con ella a su salida. Sin embargo, el Jovende-quince-años no logra salir de la cueva por traición de sus hermanos, al tener hambre quiere comerse la oreja de la cabra, que en realidad era la de un demonio, quien le ofrece liberarlo siempre y cuando no se coma la oreja. El Joven-de-quince-años, al salir de la cueva, va a buscar a su amada y la recupera gracias al anillo que le había dado antes.

11 La traducción de Arguedas dice: «Y ella se olvidó. El espanto de ser devorada por el lagarto oscureció su memoria». Lo que está entre paréntesis es traducción nuestra. 
En los cuentos que Arguedas e Itier recogen existen elementos relativamente comunes que quiero resaltar. Están presentes aquellos sujetos que son los «asustados» (mancharisqakuna): los dos jóvenes en busca de sus enamoradas, la joven esposa y los «hermanos» del Joven-de-quince-años. También hay un factor externo que produce el miedo: los muchachos de blanco, el lagarto-marido y la cueva con alimañas. Hay una enseñanza sobre el miedo: no ir tan lejos, discutir con el esposo y luchar para salir airoso; en los tres casos hay una confrontación para vencer el miedo. Dicho en quechua, existe un macharisqa (los jóvenes), producido por un manchachi (muchachos misteriosos, el lagarto, la cueva y las alimañas) y hay un resultado: manchasqa (una experiencia de miedo en los sujetos). ¿Qué significado tiene el lenguaje mítico de los cuentos? Los seres misteriosos, monstruos y los espacios naturales extraños existen en la narrativa social. Materia que requiere mayor exploración.

En segundo lugar, en la tradición de las ciencias médicas y sociales hay maneras de entender el fenómeno del susto o del mancharisqa. Los pioneros de los estudios de los males culturales son Valdizán y Maldonado (1922). Para estos autores, el susto es «[...] el traumatismo psíquico intenso provocado por una emoción de espanto. [...] La patogenia del susto es explicada por los indios como una ausencia más o menos prolongada del espíritu del enfermo» (1922: 61).

Recogiendo información de la tradición, mencionan que «el susto debió adoptar la variedad de formas de depresión psíquica y de desmedro orgánico» (1922: 86). Esta tradición es seguida por Cavero (1988), que en 1965 publicó un fascículo titulado «Supersticiones y medicina quechua». En el capítulo IV desarrolla sobre el mancharisqa, shogpi, alman chuqasqa (mal de susto, mal de espanto). Cavero dice que «Para el curandero indio, la mancharisqa, se debe a la dislocación de ciertas funciones psíquicas; y emplea para designar este trastorno, el vocablo Yuyayninmi Chinqarqusqa, el enfermo ha perdido el ánima o juicio» (1988: 33).

Cabieses (1993) también toca el tema del susto, como científico dedicado a la neurología señala que se trata de un fenómeno común en toda América Latina. Piensa que la «racionalización de esta dolencia no es difícil» (1993: 314) porque está vinculado a la noción del «alma». Pues,

[...] la noción de la pérdida o robo del alma se basa en que la personalidad es divisible. [...] podríamos ponernos de acuerdo si dijéramos que tenemos un alma consciente y un alma subconsciente. Uno puede perder o ampliar su conciencia y uno puede entrar en conflicto, reprimir o dejarse invadir por la mente subconsciente. (1993: 134) 
[...] darle la moderna denominación de «estrés» originado por una impresión violenta o intensa en una persona que, por razones educativas y culturales, es particularmente sensible y desarrolla reacciones psicosomáticas severas y prolongadas ante un estímulo determinado. (1993: 316)

En la tradición de las ciencias sociales, Polia (1996) identifica el «susto» de esta manera:

a) Un fuerte trauma físico y/o psíquico [que] interrumpe el estado normal de la conciencia e impide la actividad de control de la mente racional; b) En el estado momentáneo de confusión psíquica, la «sombra» (alma) se separa del cuerpo; c) Sustraída al control de los sentidos y de la razón, la «sombra» (alma) se halla indefensa y expuesta a los peligros del «otro mundo», el de los «encantos» que empieza donde acaba la conciencia ordinaria y viene raptada. (1996: 512)

Por su parte, Cáceres, en un trabajo muy importante, señala que el susto o mancharisqa es «la perturbación angustiosa, generada a consecuencia de la pérdida violenta y sorpresiva del 'animu', 'ispiritu' (sic) o 'alma' de los runas o personas» (2008: 56). Bianchetti (2008), a su vez, distingue los sustos causados 1) por «la separación brusca del cuerpo y el espíritu» (2008: 158); 2) el susto como mal de espanto que

[...] produce un fuerte choque emocional o psicológico, que altera al individuo llenándolo de angustia, dando origen a fuertes dolores en el pecho, pérdida de fuerza vital, con la sensación de que el cuerpo sin ánimo, e incluso la supresión de los sentidos, estados estos que atribuyen a la pérdida del espíritu. (2008: 159)

Y 3) el mal del susto simple o colerina: «debido al estado de mal humor y agresividad que toma al paciente [...] la persona sufre un estado de alteración mental y un desequilibrio neurológico y emocional que trastorna su vida incluyendo su contacto con los demás» (2008: 163).

Cutipa, a su vez, menciona que la persona que enferma del susto «no es consciente de ello, los efectos se manifiestan con el malestar general» (2009: 217).

Estos trabajos ayudan a acercarnos a una definición que puede contribuir a entender hoy en qué consiste el «susto» o mancharisqa ${ }^{12}$. Aquí se requiere de una anotación lingüística y de hacer un poco de historia para llegar a una probable «definición» que ubique lo que podría significar

12 En el norte del Perú se dice también «espanto», aunque las explicaciones de Polia (1996) tratan de diferenciarlo del «susto». 
el término en cuestión. El término «susto» es equivalente a «miedo», sabiendo que susto (del latín sub-citare) es el movimiento o la provocación que proviene de la base o de abajo. Sabemos que miedo no tiene un claro origen y es confuso en su etimología, pero está ligado al fobos (fobia) griego. El término susto se emplea para equiparar con mancharisqa. Sin embargo, susto es un sustantivo y mancharisqa es un adjetivo que denota a una persona o a un animal asustado que se aísla. El sustantivo miedo en quechua es manchay, este es además verbo y adverbio. Por ello, cuando hablemos de susto debemos usar manchay, pero si usamos mancharisqa estamos hablando de una persona asustada o aislada.

En tercer lugar, entrando a una tradición humanista como la psicología, podemos encontrar datos que nos ayuden a explorar mejor lo que tratamos de descifrar con el término «susto» o el mancharisqa como parte del sujeto social. El miedo es un sentimiento humano, un síntoma de la condición humana que Freud (1991) denominaba angustia, producido por una fobia; es decir, el miedo producido por temor o rechazo a algo. Este algo puede ser real o ficticio. Un animal puede ser interpretado como un riesgo real, aunque de hecho no sea un peligro alguno para la persona. Sin embargo, Freud interpreta que el miedo consiste en la «posibilidad» que la persona pierda una parte de su cuerpo, que es denominado «castración». Apartándome de la explicación de Freud, se puede decir que se trata de una manera de limitar el propio deseo de realización que impide el proceso del conocer. Tomando en cuenta esto, se puede decir que el miedo es «causado» por factores que están en la experiencia humana, asociados, por un lado, a lo que fue conocido y, por otro, a lo que no es conocido y que puede presentarse de manera abrupta.

Freud, en los Tres ensayos sobre teoría sexual (1992 [1905]), menciona sobre la «angustia neurótica», que es producida por no poder obtener satisfacción de un deseo o un «afecto». En sus Conferencias de introducción al psicoanálisis («Conferencia 25: La angustia») (1991 [1916]), considera la angustia como una «señal de alarma» en el yo y una reacción ante una situación peligrosa de origen interna o externa. Distingue entre la «angustia real», que provendría del exterior, y la «angustia neurótica», que provendría de algo interno o fobia, por ejemplo: del miedo a la altura, a algún animal, a la oscuridad, a la soledad, etcétera. En este sentido, el miedo está en el interior o en el yo de la persona. Desde esta perspectiva, habría tres clases de angustia: la real, la neurótica y de la conciencia moral, y estos corresponderían al mundo objetivo real y exterior, a la persona misma (denominado por Freud como «ello») y a la conciencia o el superyo.

En primer término, el miedo o la angustia es causado por algo objetivo, real o imaginado, materialmente presente en la vida social y representa un peligro y pone en riesgo la vida de la persona. Ese algo podría ser — tomando 
ejemplos locales - un «huayco», un animal que se presenta inesperadamente, el aumento del precio de los productos, un examen de ingreso a la universidad, la situación de los hijos, el no tener un trabajo estable, la ausencia de un ser querido, etcétera. A esto se puede añadir la existencia de una quebrada solitaria, un cerro determinado, un árbol en la oscuridad, el aleteo de un animal nocturno, la sombra de algo, etcétera. Cualquiera de estos elementos puede ser un factor que provoca un «miedo», dependiendo de la manera y de la hora que se haga presente. Estos factores producen un choque, provocando una angustia o miedo en la persona. El miedo es causado, entonces, por la inusitada e inesperada noticia o aparición de algo. Se trata realmente de un factor externo a la persona, que puede ser físico o imaginado.

En segundo término, la angustia neurótica es causada por una condición real, la «pérdida» de algo que está en la misma persona, que puede ser relativo a su corporalidad o su integridad, que afecta su propia afectividad o emotividad. La experiencia de dolor y violencia genera en algunas mujeres la expectativa o angustia de la posibilidad de que su experiencia (muy presente en sí misma) se repita en sus hijos. Esta situación se convierte en una angustia neurótica en tanto el modelo de vida aparece como peligro y riesgo para sus seres queridos. El miedo permanece instalado en el ello, según Freud. En el mundo andino diríamos ukunpipuni (en su mismísimo interior). Estas anotaciones se pueden ejemplificar recurriendo a la experiencia de una persona que tiene miedo a lo que podría «venir»: como la rotura de una vajilla al utilizarla, y para que no ocurra aquello, guarda los objetos para que no se rompan al utilizarlos. De hacerlo, llevaría consigo un «complejo de culpa» anticipado de la posible rotura de los objetos. Este objeto real se convierte en un factor que causaría un miedo que conmina a que las cosas no sean usadas. La angustia, en efecto, genera en la persona estrechez en la comprensión de su propia vida, generándole imposibilidad de salir de sus problemas personales.

Finalmente, en tercer término, la marca que el miedo deja en la persona genera una norma de vida que se convierte en algo peligroso y es el factor traumático que empuja a las personas a vivir sin poder desprenderse de sus propias maneras de entender la realidad o lo que quieren para sí mismos. Cada vez que la persona quiere una condición diferente para sí misma, se le recorta la posibilidad de cambio y vuelve sobre su propia situación, para ratificarse e incluso manifestar aquello que le genera miedo, sin citar la profundidad del origen de su propio miedo: su angustia. El miedo, al que podemos identificar como angustia, está en la persona y se expresa de muchas formas. El miedo se centra fundamentalmente en el individuo mismo que está condicionado por su percepción de la «realidad» que se presenta como un factor «peligroso»y que condiciona el riesgo que tiene que tomar para aminorar los efectos de la presencia de ese factor traumático, tal como lo denomina Freud. 
De otro lado, y en otro terreno, Sartre (2009) habla de angustia, desamparo y desesperación. La angustia consiste en que el ser humano: «se da cuenta de que es no solo el que elige ser, sino también un legislador, que al mismo tiempo que a sí mismo elige a toda la humanidad, no podría escapar al sentimiento de su total y profunda responsabilidad» (2009: 36).

Desamparo «implica que elijamos nosotros nuestro ser» (2009: 51). Y desesperación significa que «nos limitaremos a contar con lo que depende de nuestra voluntad, o con el conjunto de probabilidades que hacen posible nuestra acción» (2009: 52). El planteamiento de Sartre ubica al ser humano ante sí mismo, y es este quien debe decidir como individuo o como humano el sentido de su vida. De hecho, en su obra El existencialismo es un humanismo (2009), no habla de miedo sino de lo que el ser humano debe elegir y la dependencia de la voluntad a la que está sujeto por sí mismo. Vale decir, de cómo el ser humano debería comportarse allí donde está. Y para aclarar su propia posición menciona que: «cuando decimos que el hombre es responsable de sí mismo, no queremos decir que el hombre es responsable de su estricta individualidad, sino que es responsable de todos los hombres» (2009: 33).

Por ello, aquí habría que recordar lo que Erich Fromm quería decir en Miedo a la libertad:

[...] el individuo no es un Robinson Crusoe; necesita de los otros, como clientes, como empleados, como patrones. Debe comprar y vender, dar y tomar. El mercado, ya sea de bienes o de trabajo, regula tales relaciones. Así el individuo, solo y autosuficiente, entra en relaciones económicas con el prójimo, en tanto este constituye un medio con vista a un fin: vender y comprar. (Fromm s/a: 36 )

Entonces, ¿qué es el miedo? No puede ser un asunto individual, sino un hecho social que implica un conjunto de relaciones en sus diversas modalidades, que abarca un campo basto de circunstancias, como veremos más adelante.

\section{Manchay como estructura en la cultura y la sociedad}

En esta parte quisiera distinguiry graficar los componentes del mancharisqa; es decir, sobre el sujeto que tiene el «susto» o «miedo» en su «cuerpo» (uku). La condición humana del manchay que se presenta como mancharisqa tendría dos momentos. En el primero se presentan los siguientes componentes: a) el sujeto que es tocado por el «mal»; b) esto requiere de una circunstancia favorable para el miedo; c) además, debe intervenir un factor externo como 
causante del desconcierto; y d) el mal tendría secuelas. En el segundo momento, la situación es más compleja: a) los síntomas del mal presentan manifestaciones diversas; b) las causas son poco reconocidas o son atípicas para un universo mayor; y c) las secuelas se manifiestan a través de conductas igualmente atípicas y con acciones exacerbadas.

\subsection{Primer momento}

a) Una persona (runa), sea niño, joven o adulto, mujer o varón (warmi, qari), que es vulnerable y propensa, es «alcanzada» (atacada [hapisqa]) por «algún» elemento externo. El sujeto, según la concepción común y tradicional, tiene «cuerpo y alma» y esta alma es la que «vuela» o «sale» del cuerpo cuando sufre sorpresivamente un choque (Polia 1996, Cáceres 2008). Pero, ¿qué «mal» es el que toca (hapin) al ser humano que genera la «salida» de su alma? La metáfora de la salida del «alma» o del «espíritu» por la acción de algún elemento externo nos dice de la ruptura, pero no de la naturaleza de ese mal que quiebra la vida del ser humano. Al parecer, se trata de que el choque genera un desequilibrio en los diversos niveles o dimensiones del ser humano. La sintomatología no dice nada del «agente» (manchachiq) que ha producido un mancharisqa. Solo sabemos - a propósito del coronavirus - que cada persona actúa según la información que tiene y busca una solución a un mal que cree "conocer», tal como decía una joven madre: «Sí, le tengo miedo al Covid 19 por mis padres, ambos pertenecen a la población vulnerable, además en casa estamos tomando medidas para sobrellevar este proceso».

b) De otra parte, las noticias sobre el virus avanzan a una velocidad inusitada. En estas circunstancias, el miedo se convierte en un ingrediente sin control. La información incompleta incrementa la sensación de anomia y anarquía. Los sentimientos se alteran por las normas que se deben acatar. El caldo de cultivo crece sin cesar, las personas están pendientes del número de afectados y de los muertos. El miedo se expande y se va formando una sociedad imaginada encarcelada y prisionera de sus propias imaginaciones. Las noticias que provienen de otras partes del país y del mundo alimentan la inseguridad emocional. El espacio social, gracias a los medios de comunicación, se convierte en un campo de batalla sin claridad y sin enemigos visibles, rodeado de muros también invisibles. No se conoce quién está al otro lado, salvo el genérico y enigmático «coronavirus». 


\section{Diagrama 1.}

\section{Cómo se reproduce el nuevo coronavirus}

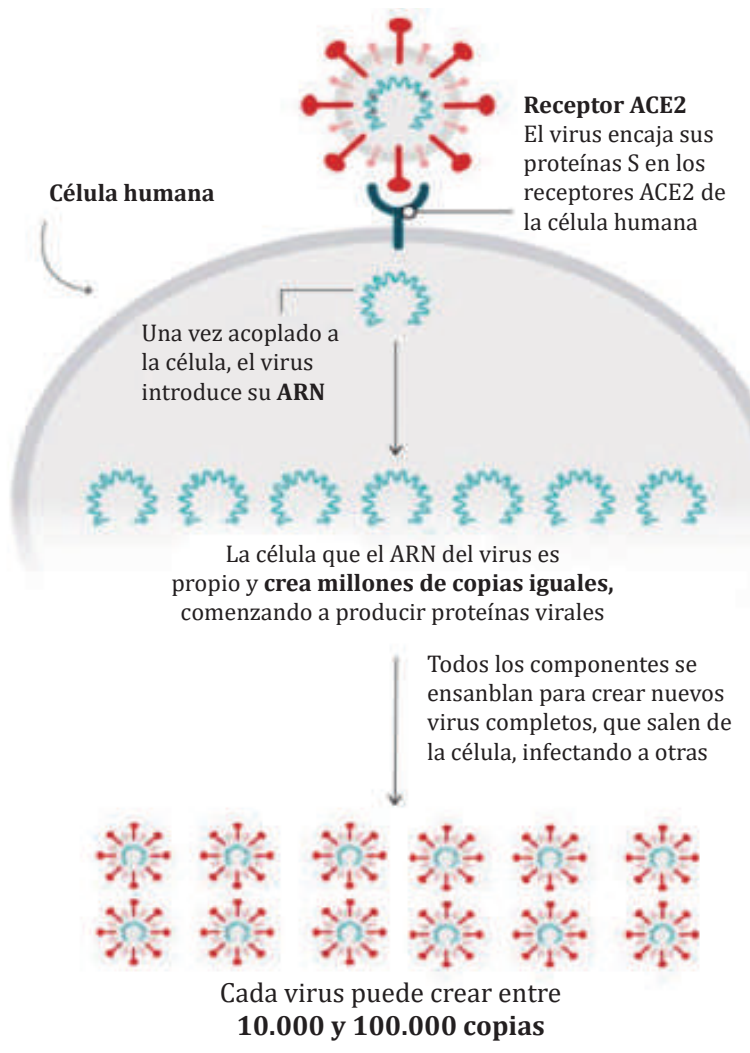

Fuente y elaboración: BBC News (2020).

c) Una vez ubicado el contexto, el enemigo emerge de muchas maneras. El enemigo (Schmitt 1998) se hace presente de manera imaginada, virtual $\mathrm{y}$ «visible». El enemigo, en la tradición andina, en materia de salud, no se conoce y solo se sabe que tiene un rostro codificado pero difuso, que toma los términos de pacha, wayra, suqa ${ }^{13}$, etcétera. No es fácil determinar la naturaleza de ese «enemigo» que causa malestares en las personas. ¿Qué significa cada una de las categorías que se emplean en el mundo andino? Estas categorías encierran una información que no ha sido decodificada aún, porque es considerada como un conjunto de «supersticiones». Del mismo modo, el enemigo que ahora acecha no es conocido. Las «supersticiones» son codificaciones que requieren

13 Pacha, wayra, suqa son términos quechuas que sirven para nombrar enfermedades culturales (Cáceres 2008, Pariona 2017). 
de una comprensión de lo que está en el fondo de los hechos. De otra manera, el enemigo se virtualiza y se difunde a través de imágenes, como la de un rostro en forma de corona en el caso del Covid-19, porque el borde del virus tiene como púas que en su conjunto forman una corona. De ahí proviene la denominación conocida del SARS-CoV-2. El diagrama 1 ha sido propalado para mostrar cómo se reproduce:

Si bien se comienza a conocer al «enemigo» y aparecen muchos frentes para entenderlo mejor y enfrentarlo, ese enemigo sigue creando miedo general por el número de contagiados y muertos (sobre todo en los de la tercera edad). La pelea se hace, por ahora, con el distanciamiento social y el aislamiento poblacional, pero se trata de una solución parcial (Ferguson et al. 2020) que, de todos modos, tendrá como resultado muchos muertos, pues el enemigo tiene un ciclo de «vida» $y$ su pervivencia está en el organismo humano que lo porta.

Finalmente, un enemigo real es construido para ser perseguido: se trata fundamentalmente de los que han retornado de viajes al extranjero (sea por visita a familiares o trabajo), ya que contribuyen a la importación del virus. Estos viajeros se convierten de pronto en «extranjeros» portadores del mal. Pero el enemigo también se construye en base a quienes no acatan las reglas de permanencia en sus hogares o modifican los precios o toman el día para hacer deportes, entre otros ejemplos. Así, la situación de la «enemistad» aparece como un enemigo difuso e incorpóreo que destroza el «alma» de las personas.

d) Las consecuencias del mancharisqa tienen diversas manifestaciones. Una de estas consecuencias se percibe en quienes han decidido quedarse en casa, no solo para no ser contagiados, sino para pasar horas cerca a su familia y volver a «aprender a vivir juntos». En ciertos casos, esa convivencia dentro del seno familiar se trata, más bien, de vivir la amenaza del mal junto a personas que han sido contagiadas. En otros, muchas familias viven la impotencia de vivir con sus niños, que no pueden ser controlados. También encontramos parejas que tienen conflictos y no saben qué hacer para lidiar con sus demonios. Todo esto y más genera tensión, estrés y angustia en muchos de los miembros. La gente mancharisqa actúa con nerviosismo y sin orientación, pierde noción del tiempo y de la realidad; en muchos se instala un sentimiento apocalíptico o armagedónico. Se pierde la sensibilidad colectiva y emerge el individualismo al ver acabarse las reservas emocionales para el siguiente día. Aparece la agresividad, mientras que los medios de comunicación —en Andahuaylas lo es 
por antonomasia la radio- exacerban ciertos estados de ánimo. Se denuncia la ausencia de las autoridades y se insiste en cerrar las carreteras para evitar el contagio. La gente pide que se ponga «mano dura» para los que no acatan las medidas de emergencia, se denuncia a los que usan transportes y a quienes siguen transitando en horas prohibidas. Otros se limitan a las súplicas: «que no llegue el mal», pues hay temor que el virus aparezca en la zona, e incluso se baraja el riesgo de que se genere cierto pánico masivo ${ }^{14}$.

\subsection{Segundo momento}

a) Los síntomas en una segunda etapa tienen manifestaciones diversas. Una vez instalado, el miedo se convierte en una angustia que aún no se manifiesta. La angustia es una sensación de que no hay salida y los espacios se estrechan aún más. El cuerpo manifiesta desórdenes inusuales que llevan a vivir en una tensión sin parangón y poco visible. En las manifestaciones tradicionales del mancharisqa el desorden corporal afecta las dimensiones de la persona. De hecho, la bibliografía señala las manifestaciones de una persona "sin alma», que consiste en vivir como si no tuviera memoria ni voluntad y con la conciencia afectada. La persona sin «alma» vive como desconectado de la realidad, formando un mundo en su propia interioridad. El miedo crea una suerte de caparazón que encierra al individuo con más temor. La cabeza gacha y las miradas perdidas dicen mucho de este síntoma. La inseguridad o la vergüenza son las dos maneras más simples de reconocer esta etapa, pero también la agresividad y la tozudez son maneras de expresar el miedo que está instalado en la persona, las que muchas veces pueden tornarse en violencia, producto de la incomprensión de la realidad y de lo que ocurre en el día a día.

b) Ahora bien, las causas del miedo son atípicas y poco conocidas. La angustia en la persona hace que esta no vea salida a los problemas

\footnotetext{
14 Poco después de reportarse el primer contagiado, un nuevo mensaje se difunde por las redes sociales de la siguiente manera: «Personal que trabaja en el hospital, y quiere que se difunda a toda la gente; a partir de mañana no salgas para nada de casa ni para ir por el pan, si puedes, congela, porque empieza lo PEOR: se cumple la fecha de incubación y empezarán a salir muchos positivos y se puede contagiar mucha gente así que es muy importante quedarse en casa y no relacionarse con nadie. Del 23 de marzo al 3 de abril debemos cuidarnos ya que estaremos en pleno pico del virus; son dos semanas, normalmente en esas dos semanas van a aparecer todos los infectados, luego hay dos semanas como de calma y ya luego dos semanas donde disminuyen. ESTAREMOS EN LA ETAPA DE MAXIMA INFECCIÓN».
} 
que comienza a enfrentar. La angustia conduce a una preocupación excesiva por los cambios que pueden ocurrir en la conducta de las personas y generar inestabilidad en la vida social. La escasez produce miedo, sobre todo de cara al futuro cercano. La posibilidad de no encontrar algo para sí mismo y los allegados puede generar parálisis, dejadez y hasta depresión. La búsqueda de algo para comer o beber provoca agresiones y lucha por conseguir lo necesario. La idea de la escasez crea tensión, pero también la ausencia del otro, y la imposibilidad de abrazarse genera sinsabores poco perceptibles. Se busca la palabra a la distancia, que calma y reabre la posibilidad del amor. La abstinencia, en cierto sentido, también crea una angustia por querer tener lo que se considera como necesario para «subsistir». Todo esto genera un mayor miedo y enturbia la vida de cada persona porque no sabe la naturaleza de aquello que lo produce, aún si lo ha experimentado antes. Por ejemplo, la experiencia de la violencia es una, pero la posibilidad que vuelva a ocurrir es desconocida y temible. Por ello, lo desconocido pende como una roca sobre la persona, que no sabe cuándo puede caer y cuáles serían las consecuencias de ese hecho. Lo contrario de lo desconocido es el confort, la costumbre, lo cotidiano, la rutina.

c) Para concluir esta parte, se puede decir que la sintomatología de la conducta que produce el miedo o el macharisqa es atípica. La experiencia del coronavirus exacerba las acciones de las personas y genera conductas poco esperadas. Libera a la persona de sus normas y costumbres para actuar anárquicamente con el propósito de lograr lo necesario para la supervivencia y mostrar su «valentía». El miedo también promueve a esconderse y no enfrentar la realidad. También hace que el sujeto se aferre a lo que más conoce, para salvarse en el momento más crucial. El miedo hace de la persona una prisionera de sus culpas y no sabe cómo salir de ese entrampamiento. El miedo la empuja a esconder su fragilidad o debilidad. Pero, también, el miedo empuja a agredir a lo que se considera como su victimario. En fin, el miedo actúa asolapado y se manifiesta, cuando menos uno espera, como traición.

Lo importante es saber que el miedo, en su segunda etapa, está instalado en uno mismo y hace que la persona esté llakllasqa. Esto significa que está marcado por aquello que lo ha dañado internamente. Esto hace que la persona sea reacia al cambio, a la novedad y a la creatividad, pues lo nuevo es poco atractivo para los que tienen la vida naturalizada, como muchos niños que tienen un miedo natural a sus mayores. Pero los adultos también tienen 
miedo, por ejemplo, los padres tienen miedo a que los hijos resulten aquello que no quisieran; las autoridades tienen miedo a que la población no las acepte y se rebele; la pareja tiene miedo a que la otra persona sea diferente a lo esperado; los sacerdotes tienen miedo a que la doctrina no sea cumplida; los maestros tienen miedo a que los niños no entiendan lo que están enseñando; la inamovilidad y el estar en casa genera angustia y fobia, etcétera.

Llegado a este punto, quisiera detenerme para tratar de definir - a modo de hipótesis - lo que es un mancharisqa y sobre todo entender los tipos de mancharisqakuna en estos tiempos (-kuna es un sufijo pluralizador). Debemos hablar de varios tipos de mancharisqakuna y que su condición implica una relación social. Empecemos con un esquema (ver esquema 1) que nos permitirá ubicar los elementos, para luego pasar a elaborar una breve explicación.

Esquema 1

\begin{tabular}{|c|c|c|c|c|}
\hline 1 & 2 & 3 & 4 & 5 \\
\hline Miedo & $\begin{array}{l}\text { Causas } \\
\text { externas }\end{array}$ & Runa & $\begin{array}{l}\text { Causas } \\
\text { internas }\end{array}$ & Expresiones \\
\hline \multirow{8}{*}{$\begin{array}{l}\text { Manchana } \\
\text { (algo o alguien } \\
\text { que da temor, } \\
\text { respeto o miedo) }\end{array}$} & $\begin{array}{c}\text { Manchachi } \\
\text { (como objeto) }\end{array}$ & \multicolumn{2}{|l|}{ Manchay } & \multirow{8}{*}{$\begin{array}{l}\text { - Cambio } \\
\text { - Debilidad } \\
\text { - Alimento } \\
\text { - Familia } \\
\text { - Extraño } \\
\text { - Oculto } \\
\text { - Nada }\end{array}$} \\
\hline & \multirow{6}{*}{$\begin{array}{l}\text { - Naturaleza } \\
\text { - Fenómeno } \\
\text { - Animal } \\
\text { - Cosa } \\
\text { - Institución } \\
\text { - Persona }\end{array}$} & \multirow{2}{*}{$\begin{array}{l}\text { Manchasqa } \\
\text { (temor, respeto) }\end{array}$} & Enfermedad & \\
\hline & & & Escasez & \\
\hline & & \multirow{2}{*}{$\begin{array}{l}\text { Mancharisqa } \\
\text { (susto, estrés, ansiedad) }\end{array}$} & Abandono & \\
\hline & & & Desconocido & \\
\hline & & \multirow{2}{*}{$\begin{array}{l}\text { Llakllasqa } \\
\text { (angustia, fobia) }\end{array}$} & No conocido & \\
\hline & & & Muerte & \\
\hline & $\begin{array}{l}\text { Manchachiq } \\
\text { (como agente) }\end{array}$ & \multicolumn{2}{|l|}{ Manchakuy } & \\
\hline
\end{tabular}

Considerando este esquema, podemos decir que el mancharisqa es una persona que pierde el control de sí mismo y que su vida multidimensional queda desordenada y dañada temporalmente en diversos grados, como producto de impactos externos no conocidos o no identificados, y su conducta puede manifestarse en aislamiento o cerrazón personal o también mediante agresión y violencia. Dicho esto, pasamos a explicar el esquema.

Columna 1: Como ya dijimos, el verbo miedo se dice manchay, pero manchana está modificado por el sufijo -na, que lo hace un sustantivo; en efecto, el término se usa para atribuir a algo superior o a alguien que se presenta con autoridad o poder, y a quien se le debe respeto o temor, pero también se le tiene miedo. Payqa manchanam, se dice a alguien que es «respetado o temido». También se puede decir de una quebrada que da miedo: wayquqa manchanam. 
Columna 2: El miedo que las personas sienten - a las enfermedades culturales - tiene, por lo general, orígenes externos. De hecho, muchos de los autores que escriben sobre este campo señalan que el mancharisqa (el sujeto que es presa de susto) ha sido causado por algo o «alguien» que se ha presentado de manera inesperada o inusitada en su vida provocando la «salida» de su alma o espíritu. Este algo o alguien es el manchachi, que puede ser un lugar escampado, la oscuridad, un fenómeno natural, un «espantapájaros», la presencia de un animal, la presencia de una persona extraña, el mensaje de una institución, etcétera. La acción del manchachi es el manchachiq. El sufijo - $q$ menciona que el manchachi es ese algo o alguien que hace asustar. El manchachiq es algo que provoca sorpresivamente el miedo y que el sujeto interpreta como el causante de su miedo. Runam makinwan mancharichiwan (una persona con su mano me ha asustado) y allqum mancharichiwan (un perro me ha asustado).

Columna 3: El runa que es objeto del susto o aquel que tiene miedo. Teniendo en cuenta los aportes de muchos autores que han tratado de definir sobre este punto, es importante revisar la concepción del runa o ser humano, no solo entre los andinos, sino en la misma medicina actual. La visión diádica del ser humano (cuerpo y alma) ayuda a resolver el mancharisqa por la «salida del alma o el espíritu $»^{15}$. Igual ocurre con la visión médico-psicológica que mira el susto o mancharisqa como un trauma o trastorno mental que padece el runa ${ }^{16}$. Sugiero la necesidad de revisar las concepciones del runa, porque el ser humano es más que una división cuerpo-alma y debiera ser considerado como un ser multidimensional muy complejo (Max-Neef et al. 1986, Sen 2000, Alkire 2002, Nussbaum 2012, Mujica 2019). Sin embargo, en esta ocasión tomemos en cuenta la nomenclatura quechua que nos dice que no se trata de un solo tipo de mancharisqa, sino de varias maneras de entender el proceso interno que la persona padece en determinadas

\footnotetext{
15 Aristóteles distingue entre sôma-psykhé-noûs. En cambio, Platón habla de soma, psyké y pneuma, que seguirá en la tradición paulina. Sin embargo, Domingo dice: «Creo que hay que contar con tres dimensiones, lo cual en cierto modo se encuentra ya en Aristóteles, al separar la psykhé, a la cual considera mortal, del nous inmortal. Igualmente, la antropología bíblica, -y para estudiarla nos vamos a apoyar en Juan L. Ruiz de la Peña— que emplea tres términos al hablar del hombre: basar, nefes y ruah. "Todo el hombre es (y no tiene) basar, todo el hombre es (y no tiene) nefes. Con otras palabras: el hombre es una unidad psicosomática, cuerpo animado y/o alma encarnada" (p. 23). Nefes es la noción central de la antropología israelita, que no es una entidad puramente espiritual al estilo de la psykhé platónica, nos dice el autor». (Domingo s/a: 76)

16 Hoy, entre otros, se conoce sobre trastornos vinculados a la alimentación (bulimia, anorexia); trastornos depresivos (tristeza, apatía); trastornos de ansiedad (pánico o fobias); trastornos relacionados con el estrés (aversión y malestar profundo); trastornos somáticos (hipocondría); trastornos del sueño (insomnio e hipersomnia); disfunciones sexuales (eyaculación precoz, anorgasmia); trastornos por adicción (dependencia, intoxicación y abstinencia); trastornos neurocognitivos (procesos mentales); trastornos parafílicos (fantasías); trastornos de personalidad (antisocial, obsesiva); trastornos relacionados al neurodesarrollo (déficits de habilidades y capacidades); trastornos esquizofrénicos y psicóticos (alucinaciones y delirios); trastorno bipolar (euforias y tristezas).
} 
circunstancias. Por lo general, podemos distinguir tres tipos de «asustados» que oscilan entre el manchay y el manchakuy; vale decir, entre el «susto» y el estar profundamente «asustado»:

a) Manchasqa: es la persona que tiene una postura de sumisión ante quien considera como superior o ante quien tiene «mejores» dotes personales; por lo general son conductas culturales denominadas «de respeto» a la autoridad o al jefe, no sin dejar de manifestar un temor reverente cargado de sumisión y dependencia. Los reconocimientos y los respetos están también embadurnados de un temor ancestral y mítico. Pero también equivale a decir que ante lo inminente se siente mucho temor e inquietud. Si tuviéramos que hacer un diagnóstico global, se podría decir que la población que estudiamos está manchasqa, vale decir, muy preocupada, inquieta, impaciente, porque tiene una actitud de subordinación, sumisión y hasta de humillación ante los acontecimientos, la amenaza del virus y del poder de las autoridades. Los niños, por otro lado, están manchasqakuna respecto de sus mayores, por ejemplo.

b) Mancharisqa: es la persona que ha tenido una experiencia o una emoción poco usual, inusitada, sorprendente, que le genera un choque en toda su persona; tiene un sentimiento de impotencia y no puede hacer lo que quisiera; por ejemplo, percibir cierta desesperanza la hace sentirse incapaz de hacer algo para ayudar a otras personas; siente el aburrimiento porque su pensamiento está en otro lugar y no donde debe estar; vive la soledad que se presenta como una realidad objetiva que le impide relacionarse con otros; queda abrumado por el estrés y la depresión que le imposibilitan resolver determinados problemas y superar sus propias capacidades; lo incapacita e inhabilita hacer lo que debería hacer, etcétera. El sufijo -ri hace que esta modalidad sea reiterativa y permanente, es un miedo cada vez más profundo.

c) Llakllasqa: es la persona en quien el miedo se ha afincado o se ha instalado internamente hasta generar actitudes de dependencia, obediencia y sumisión plena; en última instancia, como «liberado» de las relaciones de los otros. Pareciera que la violencia simbólica se hubiera instalado, como diría Foucault. El miedo instalado genera actitudes sumisas e inconscientes, muchas veces sin capacidad de cambio; la rutina y la costumbre se habrían hecho natural. El miedo se habría posicionado estructuralmente en el ser humano, haciendo más difícil — no imposible - su capacidad de levantarse y liberarse. 
Columna 4: Los tipos de «susto» presentados tienen diferentes «causas» o es una combinación de esas causas; estos tipos de «susto» afectan alguna de las partes de la multidimensionalidad del ser humano y las indeterminaciones que están presentes en la condición humana. El miedo es objetivo y subjetivo a la vez, y algunas de las causas se pueden señalar, sin ningún orden, sabiendo que el cambio y la transformación son los que determinan muchos de los miedos.

a) Miedo a la enfermedad. Unquy manchakuy es la expresión general para mostrar el miedo a la vulnerabilidad como ser humano. La presencia del mal que no se logra entender es aún más temido, y el no saber qué pasa con uno cuando está enfermo, con algún mal, hace que el miedo invada todo el mundo del ser humano y nace incluso la pregunta de si vale la pena seguir viviendo.

b) Miedo a la escasez: Muchuy manchakuy es la posibilidad de quedarse sin productos para la comida, que se reduzca o se acabe en algún momento. El muchuy es aquella necesidad que acicatea la vida biológica, individual y social, de la que nadie está exento. A esto hay que añadir las formas de sufrimiento que la persona puede experimentar por diversas razones.

c) Miedo al abandono y a la soledad: Chulla kay manchakuy es la sensación de quedarse aislado, abandonado, indefenso tanto por la familia como por la pareja. El sufrimiento puede crecer si no se encuentra un grupo social que lo acoja y lo adopte. De hecho, muchos que deben trabajar en zonas lejanas a sus hogares sienten que el abandono y la soledad les acarrea problemas, incluso reñidos con la moral.

d) Miedo a lo desconocido: Hawa runa manchakuy es la sensación de inseguridad frente a gente extraña o a extranjeros. Las personas ajenas a la vida cotidiana son consideradas como fuente de incertidumbre y como posibilidad de vulnerar la vida. Se presenta el miedo a perder lo suyo, el trabajo y los «derechos». La alteridad radical genera miedo e inseguridad.

e) Miedo a lo no conocido: Chusaq o mana risqsisqa manchakuy es la sensación de perplejidad y susto ante la novedad, pues esta es vista como fuente de peligro y amenaza de la identidad y de la estabilidad comunal. Fenómenos como un virus hacen que las personas, por ejemplo, tomen actitudes religiosas para enfrentar lo que no se sabe qué es. 
f) Miedo a la muerte: Wañuy manchakuy, finalmente, es el temor al vacío y que hace preguntarnos: ¿qué hay más allá de lo que vemos y sentimos? El miedo a la muerte sigue siendo uno de los misterios más difíciles de enfrentar. Hacia delante se nos presenta o la nada o la otra vida. Cada cual apela a lo que cree.

Columna 5: Las expresiones del «miedo», el «susto» o el mancharisqa se manifiestan alrededor del cambio y las modificaciones de la identidad, de la regularidad, de la costumbre y de lo que se piensa que es natural. Otra de las expresiones del miedo se manifiesta en el descubrimiento de la debilidad, la fragilidad y la temporalidad de la vida misma; el saberse finito y profundamente simple hace que el miedo se traduzca en temores. La ausencia de lo necesario para sostener la vida biológica se expresa muchas veces en valerse de la agresión y de la violencia para proteger la propia supervivencia. Otra de las expresiones del miedo se muestra en la ruptura de las relaciones con los otros, y la ausencia del otro genera, igualmente, incertidumbre y malestar en las personas. La presencia de personas extrañas en una comunidad genera suspicacias y dudas, situaciones ambiguas y de inseguridad. El extraño es siempre causa de preguntas que no siempre tienen respuesta. Lo que no se sabe genera mucho miedo e inseguridad, pone en duda la propia existencia y su integridad; lo que no se conoce sigue siendo el enemigo que produce miedo. Finalmente, la posibilidad de la muerte real está tan presente que ahora produce más miedo que dolor.

\section{El miedo a modo de hipótesis} La muerte es la encarnación de «lo desconocido», y entre todos los demás
«desconocidos» es el único que es plena y realmente incognoscible.

Bauman (2007: 46)

Estamos, sin duda, en tiempos de miedo, casi todos estamos manchasqa. Y si usamos los términos que la gente utiliza, deberíamos decir que tenemos el alma medio salirse de nosotros; aquello que nos da existencia y movimiento pareciera que quisiera zafarse de nosotros. No hay duda de que lo invisible se va convirtiendo en un letal enemigo y amenaza con llegar a nuestro cuerpo $(u k u)$ individual y social cuando menos se lo espera, y de hecho ya lo está, incluso sin que nos demos cuenta ${ }^{17}$. Se ha dicho hasta el cansancio que la única forma de superar el miedo (enfermedad o debilidad) es la información

17 Noticias acerca de alguien que ya está contagiado en la ciudad, atemorizan, y los comunicadores tratan de buscar a un culpable para convertirlo en el chivo expiatorio. 
adecuada y el cumplimiento de las reglas de higiene necesarias. La adecuada información es un antídoto a la ignorancia y al miedo a lo no conocido y a la nada. El enemigo que genera el miedo no solo es el SARS-CoV-2, el cual viene siendo estudiado para saber cómo será detenido usando alguna vacuna o medicamento, lo es también la conciencia de no entendernos como una comunidad.

Para concluir este trabajo quiero dejar algunas anotaciones, poniendo énfasis en algunos temas como agenda de investigación y seguimiento. Para ello, quiero afirmar que el miedo (manchay) es una emoción, una relación social, un instrumento político, pero también tiene una dimensión pedagógica.

\subsection{El miedo como emoción}

Antes de reflexionar sobre el miedo, es importante saber, como dice Camps (2017), que

[...] las emociones muestran la vulnerabilidad esencial del hombre [...]. Las emociones ciertamente ponen de manifiesto nuestra forma de ver el mundo, en tanto humanos, puesto que tendemos a estar tristes por la misma razón, o en tanto individuos con un carácter específico o con una sensibilidad especial hacia ciertos fenómenos. (2017: 38)

En efecto, el miedo es una emoción de fragilidad y una experiencia personal que hace sentir cierto desorden en el mundo individual e interno, es como un chaqway runa kayninpi (confusión interna), pero también en el mundo social. La experiencia de fragilidad es la sensación de la «presencia» de algo inusitado que convierte a la persona en algo endeble y abarcable.

El mundo de las emociones humanas, por su fragilidad, puede ser «descompuesto» o desarticulado. Pero, ¿qué es lo que se «desordena» en el mundo ( $u k u$ ) del ser humano (runa)? ¿Qué hace que incluso «el alma» se «vaya»? Un hombre des-almado es pues el que pierde el alma, vale decir, pierde su conciencia y se convierte en un «fuera de sí». La probabilidad de quedarse sin alma o sin conciencia es bastante alta como producto de un choque (cualquiera que fuera). La presencia de lo inusitado o lo no usual trastorna - en diversos grados - el $u k u$ (cuerpo complejo) de la persona por la intervención de elementos de origen natural, lugares, plantas, animales, fenómenos climatológicos, acciones humanas —entre las que está la acción o presencia de los extranjeros (Najarro 2019)—, etcétera. Es verdad que la persona «asustada» acusa muchos síntomas que muestran el desorden en su vida cotidiana. Podríamos decir que se trata de una forma del mal 
conocido como «enfermedad cultural»; sin embargo, se trata de un choque emocional y social en diversos grados que afecta la vida de la persona y su comunidad inmediata. Como decía una anciana mujer, es «la preocupación» la que se instala en la persona, que no la deja tranquila. En suma, el «miedo» (manchasqa) es la «preocupación» y el no saber cómo resolver un problema creado por la misma persona.

Las emociones se derivan de la incertidumbre, del no conocimiento de algo que sentimos; en este sentido, el miedo es producido en el campo cognitivo y no solo en la experiencia. Si el miedo es una emoción, producida por aquello que no conocemos y de la experiencia que se presenta como peligro y amenaza, entonces lo impredecible y lo que fluctúa se convierte en la real posibilidad y materialidad de ese miedo. Es posible que el golpe no llegue, pero la creencia de que llegará aterroriza aún más y paraliza a la persona y a la sociedad. Por ello, la sensación de la fragilidad se expresa en el miedo a la enfermedad, al envejecimiento y a la soledad.

El miedo, [...] es un estado de ánimo que se sustenta en creencias o en sospechas que luego serán confirmadas o refutadas. Es una emoción que mira al futuro y no al pasado. Uno no siente miedo por algo ya ocurrido, sino, en todo caso, de que eso, que no fue placentero ni agradable en su momento, vuelva a ocurrir. (Camps 2017: 182)

La probabilidad de la ruptura del equilibrio interno o social es denominada de muchas maneras: como shock (choque), traumatismo psicológico (ruptura, herida interna), angustia (estrechez vivencial), ansiedad (opresión), estrés postraumático (post herida), anomia (sin reglas), anarquía (sin gobierno), etcétera. Las denominaciones específicas dependen de las disciplinas que reconocen etiologías relativamente precisas. Las diversas disciplinas debieran acercarse sin tipologías previas para establecer fenomenológicamente lo que ocurre en la vida del poblador andino.

Sin embargo, el manchay quechua habla de la ruptura, de una desagregación emocional; es como la herida que la persona padece por alguna causa externa. En el quechua se prefiere hablar del «sujeto asustado», quien padece una desarmonía de sus dimensiones como persona y por ello está manchasqa (muy preocupado), mancharisqa («asustado») o llakllasqa (dañado), según la gravedad de los hechos. Este término, llakllasqa, es explícito para mostrar a quien experimenta una profunda «herida» interna que se puede expresar en el silencio, en una reacción repentina, en un odio inusitado contra alguien, aversión y agresión contra algo que representa la causa de su dolor (llaki). La persona que padece alguna de las formas del «susto» experimenta un desarreglo de sus partes internas (runa ukunpi) que se explicita en el «cuerpo» externo (hawa) y en sus relaciones con la 
colectividad. No sabemos la magnitud de ese desarreglo, solo sabemos - siguiendo la terminología existente- que el choque genera incluso la «salida» del «alma». La «salida» del alma deja al ser humano chaqrusqa (descompuesto) y sumido en la confusión y el desconcierto (pantasqa). El «alma», que sería el factor que integraría las diversas dimensiones de la persona, se «va». Quizá por eso Camps dice:

No somos dioses, seres omnipresentes y omniscientes, razón por la que muchas de las cosas que nos afectan escapan a nuestro control y, por ello, suelen afectarnos negativamente, porque tememos perder lo que queríamos y hemos conseguido, porque echamos de menos lo que ha desaparecido, porque nos asusta lo que no conocemos. (2017: 38)

De otro lado, las diferentes maneras de expresar el miedo pueden presentarse en diversas facetas, tal como lo dice Zhou (2020):

[...] tales emociones y comportamientos extremos incluyen: ansiedad, depresión, ilusión, inquietud, discurso o acciones incontrolables e inapropiadas, o incluso rechazo violento o evasión de la cuarentena e ideación suicida. (2020: s/p)

Los rostros más sutiles permanecen impávidos ante los otros. Y por ello El miedo es más temible cuando es difuso, disperso, poco claro; cuando flota libre, sin vínculos, sin anclas, sin hogar ni causa nítidos; cuando nos ronda sin ton ni son; cuando la amenaza que deberíamos temer puede ser entrevista en todas partes, pero resulta imposible de ver en ningún lugar concreto. «Miedo» es el nombre que damos a nuestra incertidumbre: a nuestra ignorancia con respecto a la amenaza y a lo que hay que hacer - a lo que puede y no puede hacerse- para detenerla en seco, o para combatirla, si pararla es algo que está ya más allá de nuestro alcance. (Bauman 2007: 10)

El miedo, entonces, solo nos muestra la fragilidad de la que estamos formados en nuestras relaciones con la naturaleza y la sociedad en general. Lo vulnerable, lo endeble que somos, se manifiesta en nuestra misma humanidad que tiembla ante lo inusitado o lo insólito. También lo extraordinario hace del ser humano un ser sin control y dócil. La sensibilidad convierte al ser humano en lo que es, la última capa de lo que hay.

\subsection{El miedo como una relación social}

El miedo es una emoción individual, pero es también una emoción compartida y esto implica una relación social en diversos grados. El miedo que siente uno 
no se queda en sí, se comparte o se transmite de alguna manera. El otro lee en el rostro de uno el desasosiego y la confusión. El miedo se socializa de a pocos. Invade las relaciones sociales y se instala en la colectividad en forma de relatos o mitos. La ausencia de otro genera miedo, la pérdida de los seres queridos se manifiesta en dolor y puede paralizar, anular a la persona y hacer perder la memoria. El miedo aparece allí donde no está el que debe estar y está el que no debe estar. La amistad y la enemistad se grafican en el amigo y el enemigo, respectivamente.

Por ello, el miedo que sobrecoge es sobre todo de origen humano, que se expresa de diversas formas a través de la acción. La violencia, individual o estructural, se vincula con el otro bajo obediencia y sumisión. La violencia es siempre, para la persona que lo padece, desconocida. La ferocidad con la que se tratará a la víctima es siempre inimaginable. Lo inesperado puede ser interpretado como incomprensible. La visión del enemigo aparece de manera mítica porque no se conoce las consecuencias de la relación en potencia. Las relaciones con lo desconocido, imaginado o no, genera desconfianzas mutuas y estrecheces. El enemigo aparece donde se cree que hay peligro de cualquier envergadura; es el peligro o la amenaza que se constituye como enemigo «externo» o «interno», y estos son culpables de los males o problemas que vive la persona o la comunidad. Por ello, el «miedo tiende con demasiada frecuencia a ser demasiado estrecho» (Nussbaum 2014: 389).

La relación social crea no solo enemigos, sino estigmas con los que se debe lidiar para no ser presa de ese enemigo especial.

El estigma perjudica a todos al crear más miedo o enojo hacia las personas comunes en lugar de la enfermedad que está causando el problema. Podemos luchar contra el estigma y ayudar a no lastimar a otros brindando apoyo social. (Zhou 2020: s/p)

No es fácil enfrentar aquello que es estigmatizado. En el mundo quechua un estigma es como una cicatriz $(\operatorname{sir} a)^{18}$. Es como una marca de la que una persona no puede desprenderse y que es causada por alguna enfermedad. Se le dice chipru, por ejemplo, a quien ha sido dañado y dejado con marcas por el sarampión o la viruela.

El peligro de estigmatizar está presente siempre. Algunas características pueden generar formas de exclusión y discriminación, empeorando las relaciones sociales. De razón, Zhou, en tiempos del coronavirus, menciona:

[...] el estigma es la discriminación contra un grupo identificable de personas, un lugar o una nación. El estigma se asocia con una falta de 
conocimiento sobre cómo se propaga el COVID-19, la necesidad de culpar a alguien, los temores sobre la enfermedad y la muerte, y los chismes que propagan rumores y mitos. (2020: s/p)

Por ello, es poco probable que las diversas formas de discriminación desaparezcan, pues la nacionalidad, el origen, la ocupación, el género, siempre serán excusa para discriminar a las personas. Y en este contexto, si alguna persona ha sido contagiada, ciertamente, será rechazada o generará aversión en su entorno inmediato.

El miedo se encarna en la aversión, en el rechazo o en la exclusión. Pero también el que tiene miedo busca esconderse y no mirar a su alrededor. El ensimismamiento y la capacidad de protegerse son maneras de preservarse a sí mismo. En el fondo, el miedo encapsula y aísla a la persona para vivir su propia muerte. Es probable que lo que dice Nussbaum tenga sentido: «El miedo se alimenta de la separación y se agrava con las imágenes de fuerza» (2014: 402). Manchakuspaqa wichqakunkuyá kikillanpipuni (El que tiene miedo, indefectiblemente, se encerrará en sí mismo). En efecto, el encerrarse en sí mismo hace perder noción de la realidad y de las relaciones con los otros. Los otros pueden estar, pero es como si no existieran; los ven, pero no los miran. En las calles de Andahuaylas, el saludo cotidiano con el vecino casi ha desaparecido, todos pasan raudos para no «contagiarse»; pero, sobre todo —-detrás de la mascarilla- lo que sucede es que se ignora al otro porque ya no se sabe quién es.

La discriminación y la estigmatización son dos momentos de un único proceso. Los ejemplos míticos que hemos señalado confirman la estrechez en la que las personas han vivido en determinados tiempos. El lenguaje simbólico implica esas maneras de relaciones con los otros, por ejemplo, la pareja es considerada como un fiera salvaje y cruel que devora a la otra persona. ¿Cómo no tener miedo del otro que en lugar de ser la pareja se convierte en un «uxoríboro» (warmi mikuq) $?^{19}$ La violencia es una manera de vincularse con el otro para sostener el miedo en el tiempo. En el campo del lenguaje permanecen las «creencias» o las «supersticiones» que dicen de las relaciones sociales que aún no terminan. Pues, «el miedo y la exclusión se retroalimentan» (Nussbaum 2014: 408) y, de hecho, mantienen las maneras de vincularse sosteniblemente.

La relación social de discriminación y estigma se apoyan mutuamente. Los medios de comunicación locales hacen lo posible para construir un enemigo a quien perseguir y sobre todo «linchar», sin siquiera conocer el caso; los comunicadores pareciera que estuvieran en un estado de guerra, aunque no se sepa quién es el enemigo real. Esto me hace pensar lo que Zhou (2020) anota para el caso de los chinos en los Estados Unidos: 
El estigma y la discriminación pueden ocurrir cuando las personas asocian una enfermedad infecciosa, como el COVID-19, con una población o nacionalidad, aunque no todas las personas de esa población o de esa región están específicamente en riesgo de contraer la enfermedad (por ejemplo, los estadounidenses de origen chino y otros asiáticos estadounidenses que viven en los Estados Unidos). El estigma perjudica a todos al crear más miedo o enojo hacia las personas comunes en lugar de la enfermedad que está causando el problema. (Zhou 2020: s/p)

\subsection{El miedo como instrumento de control}

El miedo, sin duda, es también un arma política. Apelando a Robin (2009), podemos decir que el miedo político es «el temor de la gente a que su bienestar colectivo resulte perjudicado - miedo al terrorismo, pánico ante el crimen, ansiedad sobre la descomposición moral—, o bien la intimidación de hombres y mujeres por el gobierno o algunos grupos» (2009: 15).

Pero el miedo es también una «herramienta política, un instrumento de élite para gobernar o un avance insurgente creado y sostenido por los líderes o los activistas políticos para obtener algo de él» (2009: 40). El sentido instrumental del miedo hace que se convierta en un medio para un fin determinado. Robin, además, reconoce dos tipos de miedo, el primero es:

[...] el temor de una colectividad a riesgos remotos o a algún objeto —como un enemigo extranjero- ajeno a la comunidad, el segundo es más íntimo y menos ficticio, se deriva de conflictos verticales y divisiones endémicas de una sociedad, como la desigualdad, ya sea en cuanto a riqueza, estatus o poder. (2009: 45)

El enemigo por antonomasia:

[...] no es cualquier competidor o adversario. [...] Sólo es enemigo el enemigo público, pues todo cuando hace referencia a un conjunto tal de personas, o en términos más precisos a un pueblo entero, adquiere eo ipso carácter público (Schmitt 1998: 58-59).

Los enemigos públicos son las personas contagiadas por el coronavirus y son quienes, potencialmente, pueden contagiar a otros al hacer caso omiso de las reglas que restringen el tránsito. Así, el enemigo es todo aquel que al no acatar las leyes impuestas se hace promotor pasivo del coronavirus. En este contexto, los medios de comunicación se convierten en los guardianes de la «salud pública», solicitando «mano dura [...] el pueblo lo va a reconocer»; insistiendo: «vamos a tener contagiados... ¿cómo se van a aislar»; «tenemos fe y guardarnos en nuestras casas como manda la constitución»; «deben 
llevarlo a los que no hacen caso, deben sancionarlos y llevarlos a la cárcel o a la comisaría». Pero otras voces, en las redes sociales, también dicen:

Si nos infectamos solo tenemos que encomendarnos a Dios. No hay cura, la gente no tiene conciencia. No sabe la magnitud del virus. Que hablen en quechua. No tiene cura, entienda. Una vez que ingrese hay que tenemos que encomendarnos a Dios.

Es como decir que en Andahuaylas «la gente se quiere morir»y los que corren riesgo y peligro son los que no saben castellano. En parte habría razón, pues no todos reciben información de la misma calidad. Ni siquiera los que hablan castellano están enterados adecuadamente; en todo caso, no se trata de que una lengua u otra reciba la información correcta, sino de concebir al otro como un ignorante y por eso pasible de ser considerado como un potencial enemigo.

Esto nos hace pensar que el uso del miedo es un instrumento para tratar de controlar a la población. Se puede decir que difundir el miedo se convierte en un trabajo profesional, es como tener una autorización para amedrentar a la gente. Lo cierto es que la «enfermedad» del mancharisqa se extiende y la persona está manchasqa. La persona experimenta en su cuerpo individual y social algo no comprensible. Si consideramos que el miedo es un síntoma de un mal entre los humanos, ese mal es un conjunto de actitudes y acciones que la persona asustada realiza para expresar una crisis individual. Bauman habla de tres clases de miedo.

Los hay que amenazan el cuerpo y las propiedades de la persona. Otros tienen una naturaleza más general y amenazan la duración y la fiabilidad del orden social del que depende la seguridad del medio de vida (la renta, el empleo) o la supervivencia (en el caso de invalidez o de vejez). Y luego están aquellos peligros que amenazan el lugar de la persona en el mundo: su posición en la jerarquía social, su identidad (de clase, de género, étnica, religiosa) y, en líneas generales, su inmunidad a la degradación y la exclusión sociales. (2007: 12)

A las tres clases que menciona Bauman, habría que añadir el tiempo del manchaypacha o manchaytiempo, como se dice en Ayacucho al periodo de la violencia política. Hoy se puede volver a usar esa palabra para hablar de los tiempos del coronavirus.

La ciencia moderna está propalando suficiente información acerca de lo que es el «mal». El coronavirus o covid-19 o Sars-CoV-2 es el mal, el enemigo público, que muchos portan aún sin saberlo. Se trata de un «enemigo» agresivo, fotografiado, que afecta sobre todo a la población mayor de sesenta años, porque es el grupo de edad que se encuentra en un periodo vulnerable 
y sus defensas inmunológicas son bajas. En ese contexto, el mal se regodea al ver partir a las personas más débiles, así como a las que tratan de ayudarlas, quienes terminan en muchos casos contagiadas. Pero, en el campo político, hay personas que se visten de maldad y construyen artimañas para imponer sus criterios estrictamente individuales. La modernidad que ofrecía seguridad y horizonte se quiebra, dejándonos a medio camino.

Podemos afirmar que la variedad moderna de la inseguridad viene marcada por un miedo que tiene principalmente como objeto a la maleficencia humana y a los malhechores humanos. Este miedo se inocula a través de la sospecha de la existencia de una motivación malévola en ciertos hombres y mujeres concretos, o en ciertos grupos o categorías de hombres y mujeres, y, a menudo, también a través de la negativa a confiar en la constancia, la dedicación y la fiabilidad de nuestros compañeros humanos, una negativa que viene seguida, de forma casi inevitable, de nuestra nula disposición a hacer de esa compañía algo sólido, duradero y, por consiguiente, digno de confianza. (Bauman 2007: 170)

La administración política del miedo genera, por ello, réditos a la élite y le da confianza, siempre y cuando sus manifestaciones vayan acompañadas de beneficios no solo económicos, sino también simbólicos. La crisis económica se puede administrar con una medida redistributiva para cubrir las necesidades básicas de los beneficiarios. En cambio, el rédito simbólico pasa necesariamente por el reconocimiento de acciones estratégicas y heroicidades que se reconocerán solo más tarde. Sin embargo, el manejo del miedo no es propiedad de la élite, porque «el miedo es una fuerza centrífuga: disipa la energía potencialmente unida en un pueblo» (Nussbaum 2014: 390). Y esto es lo que nos sugiere pensar que el miedo también es pedagogía.

\subsection{El miedo como pedagogía}

Nussbaum afirma que «el miedo es muy útil, necesario incluso. Nos aparta del peligro. Sin sus impulsos, estaríamos todos muertos» (2014: 386) y añade que «el miedo se alimenta de la separación y se agrava con las imágenes de fuerza; ninguna sensación de fraternidad puede abrochar las fisuras creadas por una arquitectura como esa» (2014: 402).

Con ello, la única forma de enfrentarse al miedo es estar en comunidad y sostener la solidaridad. Los peligros acechan y apartarse o aislarse de la comunidad pone en evidencia la posibilidad real de ser atrapado por el miedo e incluso perder el «alma». El rol pedagógico del miedo ha estado siempre presente en la vida de las comunidades. Las narraciones míticas no solo recuerdan que uno no debe alejarse de la comunidad, sino no aislarse. El aislamiento psicológico y social es ocasión para perder el «alma». La 
noción de «alma» está muy ligada a la conciencia y la responsabilidad que la persona tiene de sí misma. Aquel que deja conscientemente lo que debe hacer hace de su responsabilidad una ocasión para mostrar su propia fragilidad y vulnerabilidad. Tal vez por eso:

[...] los miedos nos impulsan a emprender medidas defensivas, y las medidas defensivas dan un aura de inmediatez, tangibilidad y credibilidad a las amenazas reales o putativas de las que los miedos presumiblemente emanan. Es nuestra respuesta a la ansiedad la que convierte las premoniciones sombrías en una realidad cotidiana para nosotros, dotando de carne y hueso a lo que, de otro modo, no sería más que un fantasma. (Bauman 2007: 171)

La conciencia es la clave para enfrentar el miedo y el terror, y en el fondo es enfrentarse al mal que arrecia, unas veces sutilmente y otras veces con descaro, como dice Baudrillard (1993).

Porque

[...] la maldad no se detiene, continuamente está en movimiento, va de principio a término; y al revés, principio y término son lo mismo, como es igual la causa de la causa, el ojo ciego que no ve, ni tampoco sabe que no ve. (Montalvo 2012: 105)

¿Qué hacer para detener el miedo y la maldad que va en él? No es fácil responder a esta pregunta, pero Rodriguez da una pista que puede ayudarnos a explorar, pues

[...] es interesante destacar que el miedo, así como puede paralizarnos de terror, también presenta una fase paradójica: atraer, cautivar, seducir. Es decir, por un lado, ejerce una suerte de rechazo centrípeto, mientras que por otra tiene una atracción centrífuga. Para lo cual utiliza -en general-dos vías: 1) la estética y 2) la práctica de actividades riesgosas. (2013: s/p)

Sin embargo, tanto la estética como las actividades de emprendimiento (que tienen un riesgo) deben pasar por la conciencia de que somos parte de un todo, como se diría en quechua: somos un lliw o un llapan, vale decir, que somos una colectividad.

Por ello, es necesario que tengamos conciencia de nuestra misma humanidad y de nuestro ser runa en un contexto histórico concreto. La pedagogía significa aprestar los conocimientos necesarios para socializar y mantener a raya el aislamiento en todos sus sentidos: individualismo, egoísmo, egolatría, ensimismamiento, autarquía, anarquía, personalismo, exclusivismo, 
encerramiento, etcétera. Pensando desde la historia de los andes, es preciso actuar con la conciencia abierta, vale decir, yuyaywan. Este término quechua dice que tener conciencia (ukusunqu) es volver (hacer memoria) a las interioridades del ser humano para actuar con rectitud (nanachikuywan), con responsabilidad. El punto de partida social quechua que debe seguir siendo construido no es solo un ñuqayku (nosotros que excluye), sino - y sobre todoel ñuqanchik (nosotros que incluye). La tarea de una conciencia colectiva no ha terminado, está en conflicto permanente con un individualismo que busca afincarse en una sociedad cada vez más moderna.

Para concluir este trabajo, consideramos que el miedo da miedo, pero la única forma de sacudirse del miedo es hacer lo que sabemos, pero en comunidad. Y para ello es necesario tener conciencia clara de nuestra condición de vulnerabilidad y fragilidad. Después de todo, el ser humano es frágil y la muerte está siempre cerca. A fin de cuentas, ¿cuántos años necesitamos vivir como individuos?

Aunque el desarrollo del ser humano, cada vez más lento, cada vez más individualizado-colectivizado, cada vez más incierto, azaroso por su carácter de auto-iniciación necesita ahora mucho más que la esperanza de 70 a 80 años de vida. (Morin 2011: 372)

La finitud, realmente, nos rodea y nos tiene entre sus manos sin posibilidad de zafarnos y esto también da miedo, pero hay manera de enfrentarlo haciéndose más individuo y más colectivo.

Lo anterior convoca a tener conciencia de pertenencia a un sistema y a una colectividad que podemos llamar de muchas maneras y aquí denominamos pachamama. Esta es la base que históricamente nos hace decir que todos somos «polvo» y en "polvo» vamos a convertirnos. Formamos una única realidad y una misma naturaleza: somos tierra con conciencia, como dijera Teilhard de Chardin (1974), pues solo somos la noosfera de lo que existe. Esto nos hace aún más responsables del mundo en el que está también nuestro cuerpo y nuestra inteligencia.

De otro lado, tener la conciencia de que nuestra vida es interdependiente política, económica y socialmente, nos invita a intercambiar y distribuir, o compartir, todo lo que se produce, construye y levanta. La sensación de poderío político, económico y social ha sido cuestionada por un diminuto virus y ha puesto en tela de juicio el sistema que hemos construido pensando que desde el poder se puede ordenar la vida. En efecto, lo que parecía sólido se va esfumando en el aire y nos ha hecho pisar tierra y hacer pensar que somos parte de esta tierra y que nuestro poder es limitado. Todos dependemos de todos, nadie es prescindible. 
Tener conciencia es saber que no solo somos parte del Estado, sino que hacemos un Estado, pero diferente al estilo de Tomás Hobbes, que quiso hacer de la violencia la marca de este Estado y que el mercado quiso tenerlo para sacar provecho para sus fines. La racionalidad instrumentalista requiere ser transformada en una racionalidad comunitaria que sea capaz de hacer del mercado una forma de hacer intercambios de los diversos conocimientos, que permiten no solo producir, sino controlar lo provisional mediante las normas y leyes que el Estado debería organizar. No basta la solidaridad, es necesaria la conciencia de ser ciudadanos con derechos inalienables y mutuas responsabilidades.

La conciencia de que el ser humano, cual sea su creencia, forma parte de un mundo, a la vez, inmanente y transcendente, es central. El ser humano vive lo indefinido y el infinito o, como diría Lévinas, el ser humano es Totalidad e infinito (2002). Esto es, el ser humano no solo es necesidad y superación de esta condición, de hecho, es un objeto que atender en sus diversas demandas objetivadas; el ser humano es ante todo relación y, por ello, antecede a la objetividad del otro la responsabilidad-para-con-el-otro. Aquí reside la trascendencia y la infinitud. Yo soy responsable del otro. ¿Qué diría el Estado o el mercado acerca de esta propuesta? ¿Solo el miedo al manchaypacha hace del Estado una entidad que se ocupa por el ser humano concreto? ¿Por qué hacer un dilema entre la salud y el mercado? Habría que recordar lo que decía César Vallejo: «Nunca la salud fue más mortal», y por ello el mercado debe estar al servicio de la vida.

Frente al miedo queda la conciencia de la solidaridad y sobre todo de la esperanza. Solidaridad es seguridad, estabilidad y permanencia de lo que es importante para la vida humana. La vida está en riesgo, comenzando ahora lo sabemos - por las personas de la tercera edad. ¿Qué solidaridad puede haber cuando los ancianos no pueden decidir dejar este mundo por sí mismos, sino que terminan siendo abandonados en hospitales porque hay otros más jóvenes que son más útiles? El dolor humano muchas veces se desvanece por la lógica de la dialéctica. Por ello, no queda otro recurso para enfrentar la muerte y el miedo a la muerte que la esperanza. Es lo último que nos queda al fondo de nuestra misma conciencia (ukusunqu). Esa conciencia está ahí, revoloteando como un picaflor (qinti) tratando de chupar el último néctar de una pequeña flor, pero siempre aleteando, así es la esperanza.

Finalmente, mirando mi mundo, este mundo andino, donde hay esperanza - como en todas partes-, quiero dejar constancia de que la gente busca el hawka kay (justicia y paz). La mentalidad individualista se filtra de muchas maneras y busca solo el bienestar del individuo, que es muy necesario, pero entiendo que la gente, enfrentando al mal desconocido y sintiendo la amenaza de su vida, lo que busca es el hawka kay que no llega aún. Hawka kay es el proyecto humano de vivir en justicia y paz, ahora 
más que nunca. La condición para estar hawka (en paz) es estar qali (tener buena salud), y para esto es necesario contar con buenos productos con que alimentarse, vale decir allin kawsaykuna.

Y en medio del miedo también hay quienes ayudan a pensar, valiéndose de diversos medios. Jorge Demetrio Ochoa (2020), por ejemplo, ha compuesto una canción, que se intitula COVID-19, para reflexionar lo que es el miedo, la que transcribimos y traducimos.

Coronavirus, chayarqamun doctorchay, doctorchay Supay unquymi kakullasqa coronavirusqa,

Runakunatas wañuchichkan coronavirusqa

Hatun llakipi tarikullanchik wawqipaniykuna, coronaviruschay, viruschay corona. (bis).

Pasñaykunapas muchawanñachu karunchakuykuspa comadrellapas qayawanñachu mikuykunaypaqpas imallapiraq rikukullani wawqipaniykuna traguchatañach upyakullsaq wawqipaniykuna coronaviruschay viruschaycorona. (bis).

Amallaraqpas hapillawaychu coronaviruschay amallaraqpas pusallawaychu coronaviruschay sipasllaraqmi warmiypas kachkan coronaviruschay sipasllaaqmmi comadrey kachkan coronaviruschay coronaviruschay viruschaycorona. (bis).
Doctorcito, doctorcito dicen que ha llegado el coronavirus El coronavirus había sido una enfermedad endiablada El coronavirus, dicen que están matando a la gente.

Hermanos y hermanas nos encontramos en un gran pesar.

Hasta las chicas alejándose ya no me dan besos

Mi comadre tampoco me invita a comer

Hermanos y hermanas no sé en qué situación estoy

Hermanos y hermanas, aunque sea me beberé un trago.

Coronavirus aún no me atrapes por favor

Coronavirus aún no me lleves por favor

Coronavirus mi esposa es aún muy joven Coronavirus mi comadre aún es muy joven. 
Manam ñuqaqa manchakuykichu coronaviruschay

Manam wañuyta manchakunichu coronaviruschay

Amigaymantam llakikuchkani coronaviruschay

Gonzalezwanñach qipanqa nispay coronaviruschay coronaviruschay viruschaycorona. (bis).

Imaynataraq qarquruykiman coronaviruschay

Haykaynitaraq qarquruykiman coronaviruschay

Pilsenchayllaytan upyakuspa

coronaviruschay

coronachata upyakuspachu

coronaviruschay

coronaviruschay viruschaycorona.

(bis).
Coronavirus yo no te tengo miedo Coronavirus yo no tengo miedo a la muerte

Coronavirus estoy muy triste de mi amiga

Coronavirus seguramente quedará con González.

Coronavirus no sé cómo botarte Coronavirus no sé de qué manera podría botarte Coronavirus bebiendo mi Pilsen Coronavirus bebiendo mi Corona.

\section{A modo de conclusión}

Llegado a este punto, no puedo dejar de pensar en el miedo que tenemos los seres humanos, y manifestar la importancia de nuestra vulnerabilidad y fragilidad. Sin embargo, mutatis mutandi, todos los seres humanos también tenemos reservas para salir de ese miedo y la esperanza de seguir viviendo de diferente manera.

Empero, el capitalismo se reafirmará en sus principios, los capitalistas y los aprendices de capitalistas harán lo posible para recuperar el tiempo perdido, pues para ellos el tiempo sigue siendo oro.

Las poblaciones volverán a sus andanzas, los remedios y la vacuna estarán en el mercado a un costo que el Estado cubrirá (o quizá no); las personas volverán a abrazarse y encontrarse en horas de jolgorio, porque el «enemigo» habrá sido, relativamente, derrotado. Hasta que aparezca el siguiente, con otra cara y de otra forma.

A pesar de todo esto, la esperanza de seguir viviendo ya no tendrá con nosotros a las personas queridas que han sido arrebatadas inmisericordemente por el virus, pero también por la indolencia del Estado y el mercado. 
¿Qué habremos aprendido de este proceso? Muchas cosas, pero quizá habría que recordar lo que Pablo Servigne y Gauthie Chapelle habían propuesto en su libro Lientraide, lsautre loi de la jungle (2017) — La ayuda mutua, la otra ley de la jungla- - y que en quechua se podría decir: Ayninakuna, sallqapi huknin kamachikuy. Pues creo que no hay otro camino para salvar el mundo. Necesitamos reconstruir la solidaridad, la cooperación, el ayninakuy.

Jueves santo, 2020.

\section{Referencias}

Academia Mayor de la Lengua Quechua-AMLQ (2005). Diccionario Quechua Español - Quechua Qheswa - Español - Qheswa Simi Taqe. Cusco: Gobierno Regional del Cusco.

Alkire, S. (2002). Valuing Freedoms. Sen's Capability Approach and Poverty Reduction. Oxford: Queen Elizabeth House.

Arguedas, J. M. (2012a). Obra antropológica. Lima: Editorial Horizonte, tomo 3.

Arguedas, J. M. (2012b). Obra antropológica. Lima: Editorial Horizonte, tomo 5.

Baudrillard, J. (1993). La transparencia del mal. Ensayos sobre los fenómenos extremos. Barcelona: Anagrama.

Bauman, Z. (2007). El miedo líquido. La sociedad contemporánea y sus temores. Barcelona: Paidós.

Benson, A. (2014). La plaga. Editor digital: Samarcanda.

Bianchetti, M. C. (2008). Cosmovisión sobrenatural de la locura. Pautas populares de salud mental en la puna argentina. Salta: Hanne Editorial.

Cabieses, F. (1993). Apuntes de medicina tradicional. La racionalización de lo irracional. Lima: AB Editores-DISELPESA, 2 tomos.

Cáceres, E. (2008). El susto o mancharisqa. Perturbaciones angustiosas en el sistema médica indígena andino. Cusco: INC.

Camps, V. (2017). El gobierno de las emociones. Barcelona: Herder.

Carreras, A., Mitre, E. y Valdeón, J. (1985). La peste negra. Cuadernos Historia 16-017. https://saladehistoria.net/biblioteca-digital/historia-16/ cuadernos-de-historia-16/

Cavero, G. (1988 [1965]). Supersticiones y medicina quechua. Trujillo: Editorial Libertad. Auspiciado por Concytec.

Cook, N. (1999). El impacto de las enfermedades en el mundo andino del siglo XVI. Histórica XXIII, (2): 341-365. http://revistas.pucp.edu.pe/index.php/ historica/article/download/8762/9147/

Cotler, J. (2006). Clases, estado y nación en el Perú. Lima. IEP. 3ra. edición, 1ra. reimpresión. 
Cueto, M. (2000) El regreso de las epidemias: salud y sociedad en el Perú del siglo $X X$. Lima: IEP.

Cutipa, Juan de Dios (2009). Curación de enfermedades. En Sanchez, R. y Sanchez, R. (Eds.). Medicina tradicional andina. Planteamientos y aproximaciones (pp. 215-224). Cuzco: CBC-Centro Medicina Andina.

De Chardin, T. (1974). El fenómeno humano. Barcelona: Ediciones Orbis S.A.

Domingo, E. (s/a). La complejidad del hombre: sôma - psykhé - pneûma. Universidad Pontificia de Salamanca. https://summa.upsa.es/high. raw?id=0000003400\&name $=00000001$.original.pdf

Ferguson, N. et al. (2020). Impact of non-pharmaceutical interventions (NPIs) to reduce COVID-19 mortality and healthcare demand. Imperial College London. https://doi.org/10.25561/77482

Freud, S. (1991 [1916]). Conferencias de introducción al psicoanálisis, parte III. 25va. conferencia: La angustia. En Obras completas, volumen XVI (pp. 357-374). Argentina: Amorrortu editores, 3ra. reimpresión.

Freud, S. (1992 [1905]). Tres ensayos de teoría sexual. En Obras completas, volumen 7 (pp. 109-223). Buenos Aires, Argentina: Amorrortu editores, 6ta. reimpresión. https://www.bibliopsi.org/docs/freud/07\%20-\%20 Tomo\%20VII.pdf

Fromm, E. (s/a). El miedo a la libertad. Versión y presentación de la edición castellana por Gino Germani. Buenos Aires: Paidós. ciudadanoaustral. org\%2Fbiblioteca\%2F04.-Erich-Fromm-El-miedo-a-la-libertad.pdf

Gonzalez Holguin, D. (1608 [1989]). Vocabulario de la lengua general de todo el Perú llamada lengua qquichua o del Inca. Lima: Editorial de la Universidad. Versión facsimilar de 1952.

Itier, C. (2004). Karu ñankunapi. 40 cuentos en quechua y castellano de la comunidad de Usi (Quispicanchis-Cuzco). Lima-Cuzco: IFEA-CBC-HOPE.

Lévinas, E. (2002). Totalidad e Infinito: ensayo sobre la exterioridad. Salamanca: Editorial Sígueme, sexta edición.

Lumbreras, L. (febrero de 1991). 500 años después. Páginas, (107): 7-16.

Max-Neef, M.; Elizalde, A.; y Hopenhayn, M. (1986). Desarrollo a Escala Humana. Una opción para el futuro. Santiago: Cepaur-Fundacion Dag Hammarskjold.

Montalvo, M. (2012). Ensayo sobre la miseria y el mal. Madrid: Tecnos.

Morin, E. (2011). El hombre y la muerte. Barcelona: Editorial Kairós.

Mujica, L. (2019). Ukunchik. La naturaleza del cuerpo y la salud en el mundo andino. Lima: INTE-PUCP/UNAJMA.

Najarro, R. (2019). Imaginarios sociales en torno a los inmigrantes venezolanos en la ciudad de Ayacucho. Altéritas. Revista de Estudios Socioculturales Andino Amazónicos, 8 (9): 159-179.

Nussbaum, M. (2012) Crear capacidades. Propuesta para el desarrollo humano. Barcelona: Paidós. 
Nussbaum, M. (2014). Emociones políticas. ¿Por qué el amor es importante para la justicia? Barcelona: Paidós.

Ochoa, J. D. (16 de marzo de 2020). Canción al coronavirus en quechua. [Archivo de video]. Recuperado de: https://www.youtube.com/ watch?v=7b9KXK8GeGw

Palomino, J. (setiembre-octubre 2014). Anotaciones sobre la Salud Pública en Ayacucho, 1920-1934. Boletín Virtual de la Asociación de Historiadores de Ayacucho, 2 (8). https://apuntesydialogos.blogspot.com/2015/03/ anotaciones-sobre-la-salud-publica-en.html

Pariona, Walter (2017). Hampiq. Salud y enfermedad en Ayacucho. Lima: UNSCHUNMSM-Pakanrina.

Polia, M. (1996). «Despierta, remedio, cuenta...»: adivinos y médicos del Ande, tomo 2. Lima: PUCP.

Robin, C. (2009). El miedo. Historia de una idea política. México: FCE.

Roca, P. (2016). El holocausto andino. Lima: Juan Gutemberg Editores.

Rodriguez, Á. (Juillet 2013). El miedo: fundamentos, rechazo y atracción psicológica. Les cahiers psychologie politique [En ligne], (23). http://lodel. irevues.inist.fr/cahierspsychologiepolitique/index.php?id=2502

Santa María, L. A. (2017). Mercurio y Taki Onqoy en el Perú del siglo XVI (tesis para optar el título de Magíster en Antropología). PUCP, Lima. http://hdl. handle.net/20.500.12404/9274

Sartre, J. P. (2009). El existencialismo es un humanismo. Barcelona: Edhasa.

Schmitt, C. (1998). El concepto de lo político. Madrid: Alianza Editorial, Primera edición.

Sen, A. (2000). Desarrollo y libertad. Buenos Aires: Planeta.

Servigne, P. y Chapelle, G. (2017). L>entraide, l>autre loi de la jungle. France: Editions Les Liens qui Libèrent.

Valdizan, H. y Maldonado, Á. (1985 [1922]). La medicina popular peruana. Lima: CISA (edición facsimilar), Imprenta Torres Aguirre. 3 tomos.

Vocabulario Poliglota Incaico (1905 [1998]). Lima: Tipografía del Colegio de Propaganda fide del Perú-Ministerio de Educación.

Zhou, W. (editor) (2020). 101 consejos basados en la ciencia del manual de prevención de coronavirus que podrían salvar su vida. New York: Skyhorse Publishing.

\section{Imágenes}

BBC News (14 de marzo de 2020). ¿Cómo se produce el nuevo coronavirus? [Imagen]. En: «Coronavirus: ¿qué le hace el covid-19 a tu cuerpo?». BBC News, Mundo. Recuperado el 20 de marzo de 2020. https://www.bbc. com/mundo/noticias-51858185 